Published in final edited form as:

Acta Biomater. 2021 October 01; 133: 153-167. doi:10.1016/j.actbio.2021.05.003.

\title{
Peptide-based supramolecular vaccine systems
}

\author{
Conor L. O'Neilla, Paresh C. Shrimalia , Zain P. Clapacs ${ }^{a}$, Megan A. Files ${ }^{b}$, Jai S. Rudraa, ${ }^{\star}$ \\ ${ }^{a}$ Department of Biomedical Engineering, McKelvey School of Engineering, Washington University \\ in St. Louis, St. Louis, MO 63130, United States \\ bepartment of Microbiology and Immunology, University of Texas Medical Branch, Galveston, \\ Texas 77555, United States
}

\begin{abstract}
Currently approved replication-competent and inactivated vaccines are limited by excessive reactogenicity and poor safety profiles, while subunit vaccines are often insufficiently immunogenic without co-administering exogenous adjuvants. Self-assembling peptide-, peptidomimetic-, and protein-based biomaterials offer a means to overcome these challenges through their inherent modularity, multivalency, and biocompatibility. As these scaffolds are biologically derived and present antigenic arrays reminiscent of natural viruses, they are prone to immune recognition and are uniquely capable of functioning as self-adjuvanting vaccine delivery vehicles that improve humoral and cellular responses. Beyond this intrinsic immunological advantage, the wide range of available amino acids allows for facile de novo design or straightforward modifications to existing sequences. This has permitted the development of vaccines and immunotherapies tailored to specific disease models, as well as generalizable platforms that have been successfully applied to prevent or treat numerous infectious and noninfectious diseases. In this review, we briefly introduce the immune system, discuss the structural determinants of coiled coils, $\beta$-sheets, peptide amphiphiles, and protein subunit nanoparticles, and highlight the utility of these materials using notable examples of their innate and adaptive immunomodulatory capacity.
\end{abstract}

\section{Keywords}

Self-assembly; Peptides; Nanomaterials; Vaccines; Immunology

\section{Introduction}

Vaccination aims to generate lasting immunological memory against both infectious and non-infectious diseases and has proven to be one of the most successful public health initiatives in history [1]. Despite this, vaccines for a number of intractable diseases like

\footnotetext{
${ }^{\sqrt{3}}$ Part of the Special Issue on Immunomodulatory Biomaterials, guest-edited by Professor Georg Duda and Doctor Taimoor Qazi. This is an open access article under the CC BY-NC-ND license (http://creativecommons.org/licenses/by-nc-nd/4.0/) *Corresponding author. srudra22@wustl.edu (J.S. Rudra).

Declaration of Competing Interest

The authors declare that they have no known competing financial interests or personal relationships that could have appeared to influence the work reported in this paper.
} 
malaria, human immunodeficiency virus (HIV), cancers, and autoimmune diseases have yet to be approved [2]. To date, approximately 100 vaccines have been licensed for clinical use in the United States, most of which utilize inactivated or attenuated pathogens [3]. While whole-organism vaccines stimulate robust and long-lived immunity, their potential to cause undesirable side effects has prompted the use of subunit vaccines that contain only antigenic proteins or epitopes derived from the target pathogen [4]. These subunit vaccines address many of the disadvantages of traditional formulations; however, their reduced immunogenicity necessitates co-administration of adjuvants to elicit immune responses sufficient for memory formation. As adjuvants are themselves reactogenic and often poor $\mathrm{T}$ cell immunopotentiators, significant effort has been devoted to developing alternative means of improving subunit vaccine efficacy [5].

As our knowledge of immunology expands, the exploitation of specific pathways continues to come into focus as a key aspect of vaccines and immunotherapies. A major goal of the cross-disciplinary field of immunoengineering is to exert spatial and temporal control over the activity of the immune system, primarily by using rationally designed biomaterials to produce safer vaccines and shed light on its less-understood functions [6, 7]. While many commonly used polymeric, metallic, and ceramic biomaterials are immunologically inert, biologically derived macromolecules such as proteins, peptides, and peptidomimetics are prone to immune recognition $[8,9]$. These biomolecules can serve as antigens, delivery vehicles, and adjuvants in subunit vaccines to localize release, protect therapeutics from proteolytic degradation, and induce the appropriate immune phenotype required for protection. Beyond their applications as prophylactic or therapeutic vaccine carriers, biomaterial-based co-delivery of multiple innate immune signals or pharmacological agents can be used as efficient combinatorial therapies $[10,11]$.

Due to their chemically defined nature, ease of de novo design and synthesis, biocompatibility, and degradability, peptides serve as useful building blocks for fabricating biomaterials with various physicochemical properties and functionalities [12]. Using the diversity of available natural and non-natural amino acids, peptides can be programmed to self-assemble into hierarchical architectures, notably fibrils, tapes, ribbons, nanotubes, vesicles, micelles, and nanocages [13]. The chemical versatility of their constitutive amino acids grants peptides a high degree of tunability, permitting sequence modifications that alter assembly, target specific cells or organs, impede enzymatic degradation, impart stimulusresponsiveness, or enable conjugation to other organic or inorganic molecules. In the context of vaccines, the multivalency of peptide suprastructures facilitates repetitive presentation of antigens on their surface, leading to enhanced uptake by immune cells and higher antibody titers relative to monovalent antigens [14]. This self-adjuvanticity allows for the marginal efficacy of subunit vaccines to be overcome without the use of toxic adjuvants and reduces the total amount of antigen required to attain protective immunity, both of which help avoid deleterious side effects. This review focuses on immunoengineering strategies based on self-assembling synthetic peptide-, peptidomimetic-, and protein-based biomaterials. The utility of this approach will be illustrated by selected studies using coiled coil fibrils and nanoparticles, $\beta$-sheet fibrils, peptide amphiphiles, and self-assembling subunit protein nanoparticles. 


\section{Supramolecular peptide-based structures}

Peptide self-assembly is a spontaneous process driven by hydrophobic packing, hydrogen bonding, van der Waals forces, and electrostatics. The wide range of available amino acids enables one to intentionally modify primary sequences to engender specific secondary structures such as $a$-helices and $\beta$-sheets that drive the reliable formation of organized suprastructures. Self-assembly can also be achieved by peptidomimetics composed of a peptide domain chemically bound to other macromolecules, including lipids, nucleic acids, and sugars. Like self-assembling peptides, whole protein subunits can undergo assembly via non-covalent interactions to form three-dimensional architectures. Here, we briefly discuss the design rules and structural determinants of four widely used classes of peptide- and protein-based nanomaterials.

\subsection{Peptide coiled coils}

The canonical structure of a coiled coil is a left-handed supercoil of two or more righthanded $a$-helices stabilized by non-covalent bonds $[15,16]$. The $a$-helices characteristic to a coiled coil typically follow a seven-amino acid heptad repeat pattern with residues specified as "abcdefg" occupying the positions illustrated in Fig. 1A, though several exceptions exist [17-19]. By controlling the identities of the amino acids at different locations in the heptad, the emergent structure of the coiled coil can be tailored. The $a$ and $d$ residues in a coiled coil's hydrophobic core can be chosen to dictate the oligomerization state between two and four helices (Fig. 1B), while further modifications can permit up to seven-helix assemblies [20-22]. It is known that asparagine residues at the a position preferentially pair with asparagine residues at the same position in adjacent helices, a property especially useful for specifying the parallel or antiparallel nature of a coiled coil [23]. The residues at $e$ and $g$ flank the hydrophobic region and often contain charge-complementary pairs that electrostatically stabilize the bundle and can select for homo- or heteromultimeric assembly and parallel or antiparallel orientation [24,25]. The exterior amino acids at the $c, f$, and $b$ positions can be tuned to affect solubility and direct higher-order assembly [26].

Taking advantage of the stable supramolecular association of $a$-helices into coiled coils, Burkhard and colleagues designed tri- or pentameric oligomers linked by a diglycine spacer and stabilized by disulfide linkages to produce self-assembling polyhedral nanoparticles with diameters of $\sim 16 \mathrm{~nm}$ (Fig. 1J) [27]. These constructs have been shown to serve as effective self-adjuvanting antigen delivery vehicles [28, 29]. Other architectures utilize synthetic dimeric or trimeric coiled coils to produce two- or three-fold symmetric hexagonal lattices that assemble into molecular cages $\sim 100 \mathrm{~nm}$ in diameter [30, 31]. These cages are composed of pepides with only a single coiled coil-forming region linked together by intermolecular cysteine disulfide linkages (Fig. 1K). Coiled coils can also assemble into filamentous structures, as demonstrated by the formation of Coil29 helical nanotubes (Fig. 1C) [26]. In contrast to purely peptide-based systems, coiled coil lipopeptides have been used as building blocks of virus-like particles (VLPs) that assemble via coiled coil oligomerization and lipid tail hydrophobic interactions [32]. 


\subsection{Peptide $\beta$-sheets}

$\beta$-sheets are composed of parallel or antiparallel $\beta$-strands that are stabilized by backbone hydrogen bonding (Fig. 1D,E) and assemble into sheets displaying a characteristic righthanded twist [39-41]. $\beta$-sheets can be designed de novo by mimicking naturally occurring peptides, referencing the measured propensities of amino acids to be found in particular secondary structures, and taking cues from established rational design methods [4245]. While early synthetic $\beta$-sheets resembled globular proteins, most contemporary selfassembling $\beta$-sheet conformations are more reminiscent of amyloids [46, 47]. As amino acid residues within a $\beta$-strand alternate between being positioned above and below the hydrogen bonding plane, peptides with alternating hydrophobic and hydrophilic residues form facially amphipathic sheets (Fig. 1F) [36, 48]. In solution, these $\beta$-strands assemble into bilayer fibrils with a hydrophobic core and hydrophilic surfaces (Fig. 1G,H) [4952]. These are stabilized by the same hydrogen bonding network as traditional $\beta$-sheets and by packing of hydrophobic residues into the fibril core, along with electrostatic interactions between charged residues and $\pi$ - $\pi$ stacking of aromatic groups, if present [53-55]. At sufficiently high concentrations, these fibrils entangle to immobilize solvent molecules and form a hydrogel, as first observed by Zhang et al. using the 16-amino acid amphipathic sequence Ac-(AEAEAKAK) $2_{2}-\mathrm{NH}_{2}$ (EAK16) [56]. $\beta$-rich self-assembling peptide morphologies can be modified by varying their amino acid sequences, although the effect is less intuitively predictable than in coiled coils. Several well-characterized amphipathic peptides with various sequences have been reported, including EAK16, Ac(RADA) ${ }_{4}-\mathrm{NH}_{2}$ (RADA16), Ac-(FKFE) ${ }_{2}-\mathrm{NH}_{2}$ (KFE8), Ac-QQKFQFQFEQQ-NH ${ }_{2}$ (Q11), and VKVKVKVKV ${ }^{\text {PPTKVKVKVKV-NH }}$ (MAX1) [56-62]. Nilsson and coworkers used the prototypic sequence Ac-(XKXE) $)_{2}-\mathrm{NH}_{2}$, where $\mathrm{X}$ denotes a hydrophobic amino acid, to show that the supramolecular- and bulk-scale properties of the resulting structures can be tuned by modifying the degree of hydrophobicity and aromaticity of the $\mathrm{X}$ residues $[63,64]$. Alterations to other peptides have similarly produced biomaterials with variable physicochemical properties [65-69].

\subsection{Peptide amphiphiles}

In their simplest form, PAs are structural or functional peptides conjugated to lipid tails that assemble into nanofibers, bilayers, micelles, or vesicles [70, 71]. The peptide components of complex PAs often contain a stabilizing $\beta$-sheet-forming domain or a polyionic domain for improved solubility. Hydrophobic packing of the alkyl tails, hydrogen bonding between the $\beta$-strands, and electrostatic interactions between the charged amino acids drive PA assembly in aqueous environments and determine their morphology, persistence length, and packing density (Fig. 1I) [72-74]. Further, when a $\beta$-sheet-forming domain in a PA contains both hydrophilic and hydrophobic amino acids, their relative positions can be altered to result in different fibril morphologies such as helical and twisted ribbons [75]. Numerous cross-linking chemistries have been applied to PA molecules to enhance the physical and chemical robustness of the resultant structures [37, 76]. This tunability makes PAs well-suited for programming molecular interactions and dictating bulk hydrogel properties [77]. Biofunctional moieties linked to the N-termini of PAs appear on the surface of the assemblies, inspiring their application as scaffolds in tissue engineering, regenerative medicine, and drug delivery [72]. 


\subsection{Protein subunit nanoparticles}

In addition to secondary structures, fully folded tertiary structures can be employed to generate self-assembled nanoparticles that imitate the natural repetitiveness, geometry, size, and shape of pathogens. Researchers have developed highly purified natural and synthetic protein subunits that offer the collective strength of multivalent antigen presentation, stability, and immunogenicity to induce levels of protective immunity comparable to live attenuated vaccines [78]. While PA micelles are stabilized by hydrophobic packing of their lipid tails, protein nanoparticles generally rely on non-covalent bonding that mimics natural viral capsids $[79,80]$. The earliest example of a self-assembling protein was isolated from the tobacco mosaic virus (TMV) and formed rod-like particles [81]. Since then, numerous VLPs composed of single or multiple pathogenic proteins have been described as templates for antigen display [82-84]. Notably, protein PIII from filamentous phage f1, Ty protein from baker's yeast, surface or core antigens from hepatitis B virus (HBV), human parvovirus, poliovirus, rotavirus, herpes virus, TMV, picornavirus, and papillomavirus (HPV) have all found considerable success in this context [85-94].

In contrast to bacterial or viral protein scaffolds, several studies have utilized nonviral, natural proteins such as ferritin, lumazine synthase, and encapsulin to fabricate self-assembling nanoparticles that present a variety of antigens [95-99]. Recently, computationally designed single- or dual-protein nanoparticles have gained prominence as platforms for the multimeric display of immunogens. Baker and co-workers have pioneered the use of self-assembling protein nanoparticles with geometries specifically tailored to present the ectodomains of influenza, HIV, and respiratory syncytial virus (RSV) viral glycoproteins [100]. Homotrimers of designed repeat proteins presenting $\mathrm{N}$-terminal helices facilitated the assembly of nanoparticles with tetrahedral, octahedral, or icosahedral symmetries, all of which presented correctly folded HIV-1 Env, influenza hemagglutinin (HA), and prefusion RSV F trimers as confirmed by antibody binding experiments. The King lab computationally designed 28-nm-wide, 120 -subunit nanoparticles with icosahedral symmetry constructed from trimeric (I53-50A) and pentameric (I53-50B) components that assemble in vitro by simple mixing [101]. Multivalent presentation of the receptor-binding domain of SARS-CoV-2 S glycoprotein on the I53-50 nanoparticles produced potent neutralizing antibody responses, indicating that such computational strategies permit rapid development of subunit vaccines candidates against urgent public health threats [102].

An attractive feature of protein subunit nanoparticles is their ability to adopt different symmetries and structures with diameters ranging from 10 to $150 \mathrm{~nm}$ depending on the proteins used in their fabrication, allowing for optimal interactions with immune cells $[78,82,95,103]$. Atomic and molecular manipulations have enabled the production of custom protein sequences as an alternative to natural proteins [104, 105]. De novo design permits the inclusion of heterologous epitopes or antigens into otherwise purely structural nanoparticles, representing a limitless array of possible antigen combinations that can be obtained by covalent chemical attachment before or after assembly. 


\section{Principles of the immune system}

The body shields itself from infectious threats through a series of concerted immune responses. During initial exposure or vaccination, dendritic cells (DCs), macrophages (MФs), and B cells, collectively known as antigen-presenting cells (APCs), internalize antigens and undergo maturation upon encountering danger signals [6]. These mature APCs then display antigens to $\mathrm{CD} 8^{+}$and $\mathrm{CD} 4^{+} \mathrm{T}$ cells through major histocompatibility complexes (MHCs) I and II, respectively, in draining lymph nodes (dLNs) and secondary lymphoid organs (Fig. 2). Antigen-specific B cells engage with $\mathrm{CD}^{+} \mathrm{T}$ cells to engender various helper $\mathrm{T}\left(\mathrm{T}_{\mathrm{H}}\right)$ cell phenotypes that initiate and polarize $\mathrm{B}$ cell clonal proliferation to generate plasma cells or memory B cells [106]. Together, these T and B cell pools form the basis of lasting immunological memory.

Instilling long-lived immunity requires recognition of danger signals by pattern recognition receptors (PRRs) on APCs to prompt upregulation of costimulatory molecules and cytokines [107]. PRRs recognize danger-associated molecular patterns (DAMPs), including alarmins and other by-products of local tissue damage, or pathogen-associated molecular patterns (PAMPs), which are molecules of microbial origin such as flagellin, lipopolysaccharides (LPS), cell wall proteins, single-stranded RNA (ssRNA) or double-stranded RNA (dsRNA), and DNA [108, 109]. Although the PRR family also comprises NOD-like receptors (NLRs), RIG-I-like receptors (RLRs), and C-type lectin receptors (CLRs), Toll-like receptors (TLRs) are the most widely studied and exploited class of PRRs due to their superior functionality and diversity [110]. TLR1, TLR2, TLR4, TLR5, TLR6, and TLR10 are located on the surface of immune cells and trigger myeloid differentiation factor 88 (MyD88) signaling that activates NF- $\kappa$ B and cytokine release [111]. TLR2 binds bacterial lipopeptides and has been demonstrated to form heterodimers with TLR1, TLR6, and TLR10, expanding its ligand repertoire. TLR4 additionally recruits and signals through the TRIF/TRAM pathway and is well-known for its recognition of bacterial LPS, while TLR5 binds bacterial flagellin [112, 113]. TLR3, TLR7, TLR8, and TLR9 are located within the membranes of endosomes and predominantly sense PAMPs of viral origin [111, 114]. These intracellular TLRs differ in their signaling mechanisms and distribution across different cell types [111]. TLR agonists are being investigated as viable targets for subunit human vaccines; notably, TLR9 and TLR4 agonists that recognize unmethylated CpG oligodeoxynucleotides (CpG-ODN) and bacterial LPS, respectively, are licensed for clinical use [115-121].

Signals delivered to T cells via APC interactions determine the strength and phenotype of the cellular immune response $[122,123]$. Primed T cells initiate a series of transcriptional programs that lead to the production of effector cytokines and rapidly proliferate into antigen-experienced effector $\mathrm{T}$ cells. After the threat is cleared, the population of effector $\mathrm{T}$ cells will begin to contract through programmed cell death pathways, leaving memory $\mathrm{T}$ cell pools that can persist for years [124-126]. Memory T cells patrol tissues and the circulatory system to neutralize previously encountered agents by performing programmed effector functions exerted through cytolytic activity and signaling to neighboring cells to enhance pathogen clearance [127]. Memory T cells can be divided into tissue-resident, effector, and central memory subsets identifiable by the differential expression of a variety of surface 
molecules, such as CD44, CD45RA, CD62L, CD69, CCR7, KLRG1, CD27, and CD127 [126].

Immunoengineering aims to improve the efficacy of vaccines and therapeutics to combat infectious diseases, cancers, and autoimmune conditions. While broadly acting substances may effectively stimulate the innate immune system, their lack of specificity may impede induction of anamnestic immunological memory. Therefore, it is critical to consider the nature of the pathogenic agent, the pathogenesis of the disease, and the type of protection required when engineering vaccines or immunotherapies.

\section{Modulating innate immunity}

Innate immune cells, namely MФs and DCs, provide the first line of defense against infections and coordinate downstream adaptive immune responses [128]. Since the 1990s, there have been substantial advances in our understanding of the innate immune system, due in part to the discovery of PRRs, their corresponding ligands, and their molecular mechanisms. While peptide-based supramolecular nanomaterials enable the design of safer vaccine platforms, a thorough understanding of their interactions with innate immune cells is required to avoid unexpected side effects.

In vivo, peptide nanomaterials quickly encounter APCs at the injection site, which have been reported to engulf particulate antigens more efficiently than soluble antigens [129, 130]. Using fluorescent labeling, Collier and coworkers showed that Q11 nanofibers are internalized as early as six hours after administration [131]. A subsequent study found that the magnitude of nanofiber internalization by DCs is dependent on the net charge of the assemblies, with positive charge enhancing uptake and negative charge abrogating uptake [132]. Interestingly, DCs that internalized Q11-OVA $323-339$ fibrils exhibited minimal activation, as evidenced by low levels of CD80 and CD86 upregulation despite robust antibody and $\mathrm{T}$ cell responses [133]. While numerous studies have confirmed that APCs readily internalize peptide-based nanomaterials, further investigation is necessary to determine if their uptake is mediated through specific receptors and if the materials trigger PRR pathways in a manner similar to pathogenic components [34, 133, 134].

The intracellular fate of peptide-based assemblies and the mechanisms that dictate their processing and clearance by APCs are instrumental in ascertaining their immunological determinants, efficacy, and long-term safety. Studies using the amphipathic peptide KFE8 showed that the self-adjuvanting potential of $\beta$-sheet-rich peptide nanofibers was due to their ability to engage autophagy in MФs and DCs [135]. MHC antigen presentation to $\mathrm{CD} 4^{+}$and $\mathrm{CD} 8^{+} \mathrm{T}$ cells was severely impaired by autophagy inhibitors or in mice deficient in autophagy pathways. This finding has significant implications for subunit vaccines, as autophagy is a homeostatic and inducible function affecting multiple aspects of the immune system, including innate sensing, inflammatory signaling, cytokine regulation, and metabolism [136, 137]. Autophagy is also crucial for clearance of neurodegenerative amyloids in Alzheimer's and Huntington's diseases; however, in vitro cellular toxicity of peptide assemblies has not been observed despite their structural similarities to diseaseassociated amyloids $[135,138]$. This is presumably because the nanofibers fibrillize 
rapidly without passing through the prolonged lag phase characteristic of disease-associated amyloids. Further, the repetitive nature of many self-assembling peptides may promote the production of antibodies capable of recognizing aggregated cross- $\beta$ morphologies such as amyloid- $\beta(\mathrm{A} \beta)$. This is supported by a study using the hydrophobic sequence VIAVIA (a double repeat of $\mathrm{A} \beta_{40-42}$ ), antibodies against which also recognized $\mathrm{A} \beta$ deposits in mouse and human brain sections [139]. Insights into the cellular actions of Q11 indicated that total knockout of the transcription factor MyD88, which is known to regulate TLR signaling, significantly reduces $\mathrm{T}$ cell responses to peptide nanofibers [131]. In contrast, using adoptive transfer to produce mice with T cell-specific MyD88 deficiency did not inhibit the immunogenicity of the nanofibers. This implies that, like other adjuvants, peptide nanofibers mobilize both MyD88-dependent and MyD88-independent signaling pathways in APCs and T cells. This is reflected in studies demonstrating higher degrees of DC maturation, upregulation of chemotactic molecules such as MCP-1 a/CCL2, KC/CXCL-1, or upregulation of cytokines such as G-CSF, interleukin-5 (IL-5), IL-6, and IL-1 $\beta[131,133$, 140].

To improve the intrinsic immunogenicity of fibrillar peptide nanomaterials, researchers have incorporated various immune ligands that can trigger specific innate pathways. $\mathrm{Xu}$ and coworkers have designed several enzyme-responsive peptide systems, including taurine-modified NBD- ${ }^{\mathrm{D}_{F}} \mathrm{D}_{\mathrm{F}}$ and Nap-FFK(NBD) $\mathrm{Yp}$, that aggregate intracellularly in the presence of esterase or alkaline phosphatase, respectively [141, 142]. A related peptide, Nap- ${ }^{{ }^{2}}{ }^{D} F^{D} F^{D} Y p$, has been shown to selectively inhibit cancer cells by modulating $N F-\kappa B$ expression [143]. Fibrils composed of Nap- $G^{D} F^{D} F^{D} Y$ functionalized with tuftsin (TKPR), a tetrapeptide from the heavy chain $\mathrm{Fc}$ of $\mathrm{IgG}$, markedly upregulated the costimulatory markers CD40 and CD80, tumor necrosis factor- $a$ (TNF- $a$ ), and interferon- $\gamma$ (IFN- $\gamma$ ) [134]. Treatment of splenocytes with the same construct resulted in the release of IL-6 and IL-12, indicative of a pro-inflammatory response similar to those elicited by some TLRs. The nanoadjuvant 3DSNA, consisting of Nap- $\mathrm{G}^{\mathrm{D}} \mathrm{F}^{\mathrm{D}} \mathrm{F}^{\mathrm{D}} \mathrm{Y}$ functionalized with adamantaneacetic acid and a polylysine tail, upregulated CD80 and CD86, inducing NF- $\kappa \mathrm{B}$ signaling [144]. Other groups have utilized cell-penetrating peptides (CPPs) conjugated to peptide nanofibers to improve uptake by $\mathrm{DCs}$, enhance $\mathrm{CD} 8^{+} \mathrm{T}$ cell responses, and reduce tumor burden, suggesting that uptake, adjuvanticity, and immune responses can be tuned by the inclusion of functional moieties [145, 146]. In contrast to exogenously functionalized fibrils, Tandon et al. showed that the peptide TR433 self-assembles into fibrils that can intrinsically stimulate the TLR4 pathway in mouse and human primary and reporter cells [147]. The antibody titers observed for TR433 co-administered with OVA were comparable to those for OVA in complete Freund's adjuvant (CFA). A related study observed that Q11-OVA $323-339$ nanofibers did not activate TLR4 but potentiated equivalent antibody responses [148]. Thus, further investigation is required to elucidate the specific advantages of dual-purpose platforms such as TR433.

The Tirrell group and others have extensively researched PAs, which are known to interact via clathrin-independent carrier (CLIC) mechanisms and whose lipid tails may initiate raftbased endocytosis for entry into MФs and DCs $[149,150]$. Further intracellular trafficking of PAs is governed by the chemical nature of their lipid chain, making them highly versatile structures for vaccines and immunotherapies $[150,151]$. The palmitic acid lipid 
tails traditionally used in PA construction do not activate TLR2, but they can be replaced by lipids that act as TLR2 and TLR4 agonists in addition to stabilizing the amphiphile nanofibers [152].

APC engagement with nanoparticles composed of natural or synthetic proteins is heavily influenced by their shape, size, charge, hydrophobicity, and antigen glycosylation [78, 153]. Various nanoparticle designs based on protein subunits, lipids, and polymers have been functionalized for engagement with APC endocytic receptors, including DC-specific intercellular adhesion molecule-3 grabbing non-integrin (DC-SIGN/CD209), dendritic and thymic epithelial cell-205 (DEC-205/CD205), mannose receptor (MR/CD206), and Fc receptor $(\mathrm{FcR})$, with different DC subsets showing different uptake affinities and outcomes for a given VLP [154-159]. Due to their favorable characteristics and suitability for largescale manufacturing in bacteria and insect cells, protein subunit nanoparticles are among the most promising vaccine therapeutics under development [82]. However, their long-term stability profiles and inherent safety concerns regarding possible contamination during their recombinant expression must be considered and addressed. The effects of nanoparticles on the innate immune system have recently been discussed in a review article by Bachmann and coworkers [160].

While supramolecular peptide assemblies based on MAX1 and other $\beta$-sheet-forming peptides are intrinsically antimicrobial, multivalent presentation of natural antimicrobial peptides (AMPs) has been used to augment this capacity [161, 162]. The structurally and compositionally diverse family of AMPs constitutes the first line of defense against invading pathogens, and all complex organisms and some microbes produce AMPs, which are typically $\sim 10-40$ amino acids long, positively charged, and contain a high proportion of hydrophobic residues that enable them to form fibrils, micelles, vesicles, or nanotubes depending on their composition and environmental conditions [163]. The generally accepted mode of action of AMPs is the destabilization of bacterial membranes by self-assembling into oligomeric structures that facilitate pore formation and cell lysis [164]. Interestingly, the ability of AMPs to regulate aspects of the immune system has made them potential candidates as vaccine adjuvants $[165,166]$. In particular, neutrophilderived defensins have been shown to regulate cytokine responses, $\mathrm{DC}$ maturation, and $\mathrm{T}_{\mathrm{H}}$ cell polarization. In mice, defensins effectively promote and enhance antigen-specific immunity, presenting an attractive avenue for the development of self-adjuvanting supramolecular vaccines [167].

\section{Modulating adaptive immunity}

Unlike the innate immune system, the adaptive immune system is characterized by specificity, immunological memory, and discrimination between self (endogenous molecules) and nonself (exogenous molecules, such as pathogenic components) [128]. Within this system, B cells generate broadly neutralizing antibodies but require assistance from follicular helper $\mathrm{T}\left(\mathrm{T}_{\mathrm{FH}}\right)$ cells to mature into long-lived plasma cells. $\mathrm{CD} 8^{+}$and $\mathrm{CD} 4^{+}$ $\mathrm{T}$ cells are the primary drivers of cell-mediated protection, recognizing antigen on the surface of APCs and differentiating into cytotoxic $T$ cells and helper $T$ cells (e.g., $T_{H} 1, T_{H} 2$, $\mathrm{T}_{\mathrm{H}} 17$ ), respectively. $\mathrm{B}$ cells recognize antigens through $\mathrm{B}$ cell receptors (BCRs) and the dense, structurally ordered antigenic arrays presented by filamentous peptide nanostructures 
or symmetric nanoparticles allow for multiple binding events between the constructs and B cells to occur simultaneously, facilitating receptor-mediated internalization of antigens $[28,148,168,169]$. Thus, the density and distribution of antigen on peptide assemblies are key features that can be used to modulate their efficacy [170]. Antigenic multivalency can also be exploited to overcome tolerance in autoimmune diseases and transplant rejection by presenting self-antigens to $\mathrm{T}$ cells in the context of tolerogenic signals and anti-inflammatory cytokines [171]. B and T lymphocytes are closely linked, as the same antigen-BCR interactions that trigger B cell signaling are necessary for downstream $\mathrm{T}$ cell responses and the subsequent long-lived secretion of antibodies by plasma cells $[172,173]$.

Though the multivalency of supramolecular peptide constructs is recognized as a significant advantage, antibody production against the scaffolds themselves could lead to vehicleinduced immunosuppression. This has been observed for adenovirus vaccines, with anticarrier immunity generated during initial exposure impeding the efficacy of booster doses. While this effect is a result of our natural ability to defend against adenoviruses, the immune system also recognizes non-pathogenic repetitive and organized structures as foreign because these patterns are largely absent from the extracellular environment. However, inherent immunogenicity of the structural components of supramolecular peptide vaccines has not been reported to date and remains an under-studied aspect of the field.

\subsection{Adaptive immune responses to peptide coiled coils}

In recent years, fibrillar coiled coils have found success as vaccine adjuvants, suggesting utility beyond applications in structural biology $[34,174,175]$. A noteworthy example is the peptide Coil29, which assembles into a tetrameric nanotubular structure [26]. Conjugation of $\mathrm{T}$ cell and B cell epitopes to the radially outward-facing $\mathrm{N}$-termini of Coil29 promotes multivalent antigen presentation and enhanced antibody and cellular immune responses, indicating potential adjuvant-like activity [34]. Due to the versatility of de novo peptide design, Coil29 nanofiber length can be regulated using capping peptides that either create kinks in the fibril or terminate its propagation, resulting in more consistent fibril lengths [174]. Immunological assessment of Coil29 linked to a CD8 ${ }^{+} \mathrm{T}$ cell epitope revealed that the capped fibrils induced higher levels of antigen-specific $\mathrm{CD} 8^{+} \mathrm{T}$ cells in lymph nodes relative to their uncapped counterparts, confirming that dimensional control over peptide assemblies may be critical for optimizing their adjuvanticity. Coiled coil peptides modified with nicotine-6-hexanoic acid and $\mathrm{T}_{\mathrm{H}}$ cell epitopes have been developed by Clegg and coworkers as nicotine vaccines to aid smoking cessation [175]. The vaccine was constructed by attaching the hapten via carboxyl-amine crosslinking at the $f$ and $c$ positions, allowing for display on the carrier surface. Antibody titers on par with alum-adjuvanted formulations were observed in mice vaccinated with the coiled coilnicotine conjugates. Inclusion of the TLR4-agonist glucopyranosyl lipid A (GLA-SE) further increased antibody levels and decreased nicotine entry into the brain by $91 \%$ compared to a saline group. In subsequent studies, multi-haptenated coiled coil carriers improved vaccine efficacy and reduced nicotine toxicity in rats $[176,177]$. In addition to de novo designed sequences, a naturally occurring recombinant flagellin protein (FliC) has been reported to assemble into supramolecular helical architectures, and modified FliC filaments decorated with the D3 envelope protein of 
dengue virus elicited strong T-independent antibody responses [178]. Thus, these structures may be applicable as vaccines for immunocompromised patients that lack $\mathrm{CD} 4^{+} \mathrm{T}$ cells.

Self-assembling peptide nanoparticles containing coiled coil oligomerization domains have been shown to generate long-lived humoral and cellular immunity in disease models including malaria, HIV, toxoplasma, influenza, bronchitis, and SARS [28, 179183]. Incorporating a TLR5-activating flagellin domain as a structural component of the nanoparticles augmented their immunogenicity [29]. Coiled coil peptides with terminal Tau or $\mathrm{A} \beta$ domains that assemble into spherical nanoparticles have demonstrated usefulness as prophylactic or therapeutic vaccines in pre-clinical models of allergic asthma, influenza, and infertility [184]. Boato et al. linked a phospholipid tail to a naturally occurring trimeric coiled coil peptide from the RSV $F_{1}$ glycoprotein to fabricate fully synthetic VLPs with size and structure comparable to natural viruses [32]. Biophysical analysis confirmed that the VLP was composed of 24 constituent trimeric coiled coils, each of which displayed three epitopes. The potency of these particles was assessed in rabbits using the model organic hapten Lucifer Yellow $\mathrm{CH}$ or a peptide sequence derived from the HIV-1 protein gp120.

\subsection{Adaptive immune responses to peptide $\beta$-sheets}

While numerous tissue engineering applications have confirmed that self-assembling $\beta$-sheet fibrils are well-tolerated, Rudra et al. reported that fibrils functionalized with immunogenic epitopes are self-adjuvanting and lead to high antibody titers against the presented antigens [148]. When the glutamine-rich peptide Q11 was conjugated to OVA $323-339$, the assemblies induced antibodies levels comparable in magnitude and persistence to OVA $323-339$ administered in CFA. Further, unlike the exogenously adjuvanted $\mathrm{OVA}_{323-339}$ formulation, the Q11-OVA $323-339$ fibrils did not cause local inflammation at the injection site. Malaria model experiments supported that this self-adjuvanticity is highly relevant to vaccine development, eliciting durable and protective anti-malaria antibodies [185]. Insights into the mechanism of action revealed a critical role for $\mathrm{CD}^{+} \mathrm{T}$ cells in the observed humoral response, which was independent of the TLR2, TLR5, and NALP3 inflammasome pathways $[185,186]$. While antibodies are relatively easy to generate, the activation threshold for efficient priming of $\mathrm{CD}^{+} \mathrm{T}$ cells is higher due to costimulatory requirements from APCs [187]. Intranasal delivery of Q11 nanofibers bearing the MHC I epitope $\mathrm{OVA}_{257-264}$ (SIINFEKL) were found to effectively protect against infection with a mouse-adapted human influenza strain (PR8) expressing OVA 257-264 [188]. Si et al. demonstrated that, compared to parenteral vaccination, intranasal delivery of Q11 nanofibers bearing the influenza acid polymerase epitope $\mathrm{PA}_{224-233}$ (SSLENFRAYV) induced higher levels of lung-resident effector and memory $\mathrm{CD} 8^{+} \mathrm{T}$ cell responses and protected mice against an influenza challenge [189]. Analysis of cell populations in the lungs of vaccinated mice indicated that Q11 nanofibers are processed by $\mathrm{CD}_{103^{+}}$lung DCs, triggering a strong antigen-specific $\mathrm{T}_{\mathrm{H}} 17$ response in the mucosal tissue and dLNs [190]. Inclusion of the panDR T cell epitope PADRE in IL-17-Q11 nanofibers increased anti-IL-17 antibody production while reducing imiquimod-induced psoriasis in mice without added adjuvants [191, 192]. Further, the declining antibody titers over time could be recovered by a recall exposure to the IL-17-PADRE-Q11 construct. In addition to eliciting antibodies against foreign proteins, peptide nanofiber vaccines targeting autologous molecules like TNF- $a$ can 
overcome B cell tolerance and generate antibodies that prevent inflammation [193]. As an alternative to monoclonal antibody therapies, active immunization is comparatively costefficient, produces lasting effects, and elicits a polyclonal response that includes different isotype specificities that can enhance the breadth of protection. Full-length proteins (e.g., GFP) can be bound to fibers using phosphonate-cutinase or other orthogonal chemistries to expand the repertoire of possible functional antibodies against pathogens [194]. In lieu of chemistries that only permit functionalization of mature fibrils, controlling the rate of $\beta$-sheet formation enables multiple full-length proteins to be incorporated without impeding self-assembly [195].

Comparable immunological results were obtained when antigens were displayed by alternative $\beta$-sheet-forming peptides such as KFE8, EAK16, RADA16, Nap- $\mathrm{G}^{\mathrm{D}} \mathrm{F}^{\mathrm{D}} \mathrm{F}^{\mathrm{D}} \mathrm{Y}$, and $\mathrm{Ac}-(\mathrm{RVQV})_{3}-\mathrm{COOH}(\mathrm{Z} 1)$, suggesting that self-adjuvanticity is an intrinsic feature of this class of materials $[134,140,186,188,196-202]$. Nanofiber vaccines can carry a wide array of antigens, including bacterial or viral epitopes and addictive drug haptens. Fibrils composed of KFE8 linked to a cocaine hapten modified at the P3 site have been shown to boost anti-cocaine antibody titers without the need for exogenous adjuvants [197]. This significantly decreased cocaine-induced hyperactivity while avoiding the potential systemic toxicity associated with the strong adjuvants required by alternative strategies. One considerable advantage of peptide nanofibers is their ability to form selfsupporting and injectable hydrogels at high concentrations, a property that can be exploited for simultaneous presentation of antigens and sustained release of immunomodulatory compounds. For example, a hydrogel formed by KFE8 admixed with the West Nile virus immunoprotective envelope protein domain III (EIII) resulted in significantly higher antiEIII antibody titers in mice than free EIII co-administered with alum [203]. Its effectiveness was also supported by reduced weight loss and a threefold higher survival rate $(60 \%)$. Woodrow and coworkers investigated optimized charge distribution and density to modulate the self-assembling properties of the model sequence $\mathrm{Z1}$ and its derivatives with substituted residues or terminal groups [196]. These peptides assembled at lower concentrations than similar amphipathic peptides, demonstrated increased hydrogel mechanical strength, and elicited robust $\mathrm{CD} 8^{+} \mathrm{T}$ cell responses.

In contrast to de novo designed peptides, the naturally occurring $\beta$-sheet-forming amyloidogenic peptide I10 (SNNFGAILSS) can trigger NF- $\kappa$ B signaling without significantly affecting cell viability in a HEK reporter cell line expressing the human heterodimer TRL2/6 [204, 205]. When an influenza A matrix protein epitope (M2e) was conjugated I10, the M2e-I10 nanofibers activated NF- $\kappa$ B signaling pathways at levels comparable to unconjugated I10 nanofibers and produced M2e-specific antibodies with or without alum; however, NF- $\kappa$ B activation was not achieved by M2e alone. While the presence of alum enhanced antibody levels following the first and second immunizations with Me2-I10, there was no significant difference following the third immunization. In mice vaccinated without alum, isotyping data revealed higher levels of IgG2a subtype, indicative of $\mathrm{T}_{\mathrm{H}}$ 1-type immunity typically associated with viral clearance [205, 206]. Beyond infectious disease and addiction models, a number of $\beta$-sheet-rich peptide constructs have been used as adjuvants in a variety of cancer models to minimize tumor burden [134, 145, 207-211]. 
While selecting from naturally occurring L-amino acids allows for control of physicochemical properties such as charge, hydropathy, and polarity, incorporating their D-enantiomers further enriches this diversity and impacts self-assembly behavior [142, 144, 202, 211-217]. The geometric change in backbone-side chain connectivity of Denantiomers makes them resistant to proteases, preventing in vivo degradation [212, 218]. To demonstrate this, Nilsson and coworkers exposed L- and D-KFE8 fibrils to three proteases (chymotrypsin, trypsin, and proteinase K) and found that while the L-KFE8 fibrils were $\sim 50 \%$ degraded after $24 \mathrm{~h}$ and $~ 95 \%$ degraded after five days, the D-KFE8 fibrils were only marginally degraded after five days [218]. Adjusting the stoichiometric ratio (1:1 or 3:1 L:D) of the enantiomers allowed for additional control over the proteolytic stability of the hydrogels. Biostability and biodistribution studies in mice demonstrated that L- and Denantiomers of Nap-GFFYGRGD degrade at different rates in plasma (95\% or L-enantiomer and $17 \%$ of D-enantiomer digested after $24 \mathrm{~h}$ ) and preferentially accumulate in different organ systems [219]. In a study comparing L- and D-KFE8 fibrils bearing OVA $323-339$, the improved in vivo stability of the D-enantiomers was associated with enhanced and persistent antibody responses while retaining the non-inflammatory status of the L-enantiomers [213]. Several D-amino acid-substituted self-assembling peptides based on the parent sequence Nap-GFFY and its D-enantiomer Nap- $\mathrm{G}^{\mathrm{D}} \mathrm{F}^{\mathrm{D}} \mathrm{F}^{\mathrm{D}} \mathrm{Y}$ have shown considerable promise as vaccines and immunotherapeutics in multiple disease models [220, 221]. Modified versions of this system include those with an added charged domain to facilitate uptake by APCs, substitution with phosphotyrosine to protect phosphorylated antigens, and the inclusion of the immunostimulatory immunoglobulin-derived tetrapeptide TKPR (tuftsin) or the nonsteroidal anti-inflammatory drug flurbiprofen [134, 144, 201, 202].

The self-adjuvanticity of peptide nanofibers has been complemented by combining them with TLR agonists to improve immunological memory. The commercialized RADA16 hydrogel Puramatrix ${ }^{\mathrm{TM}}$ has been used as an adjuvant depot for the TLR9 agonist $\mathrm{CpG}$ and the recombinant hepatitis B surface antigen (rHB-sAg) [200]. It has also been used to encapsulate PLGA microparticles loaded with granulocyte-macrophage colony-stimulating factor (GM-CSF) and insulin to recruit and activate immune cells in a type 1 diabetes (T1D) mouse model [222]. Simple admixing of KFE8 fibrils bearing the glycoprotein B (gB) epitope from herpes simplex virus type 2 (HSV-2) with TLR3, TLR7, and TLR9 agonists (polyI:C, gardiquimod, and $\mathrm{CpG}$, respectively) increased the frequency of $\mathrm{gB}$-specific $\mathrm{T}$ cells in the dLNs, polyfunctional cytokine (IFN- $\gamma$ and TNF- $a$ ) production, and HSV-2specific cytotoxicity [223]. Interestingly, the effector function of the T cells was found to be dependent on the type of TLR used. Antigenic EAK16 nanofibers displaying the HIV-1 Gag p17 protein SL9 mixed with TLR7 and TLR8 agonists (imiquimod and resiquimod) demonstrated effective internalization via the endosomal pathway, co-localization within acidic intracellular compartments, and upregulation of CD83 [198]. The nanofibers enhanced multifunctional antigen-specific $\mathrm{CD} 8^{+} \mathrm{T}$ cell responses when co-cultured with peripheral blood mononuclear cells from HIV-1-infected individuals. Although the presence of TLR7 and TLR8 agonists promoted DC maturation and T cell stimulation, the generation of antigen-specific cytotoxic $\mathrm{CD} 8^{+} \mathrm{T}$ lymphocytes was dependent on physical linkage of the epitope to EAK16. In contrast to simple admixing, the chemical versatility of amino acids and terminal peptide groups allow TLR agonists to be covalently bound to peptide 
nanofibers. In Bacillus Calmette-Guérin (BCG)-primed mice, intranasal administration of coassembled fibrils composed of KFE8 presenting Mycobacterium tuberculosis (Mtb) antigens and KFE8 presenting the TLR2 agonist $\mathrm{Pam}_{2}$ Cys (P2C) expanded CD8 ${ }^{+} \mathrm{T}$ cell pools in the lungs eightfold, resulting in an additional $0.5 \mathrm{log}$ reduction of $\mathrm{Mtb}$ burden compared to BCG alone [140]. This showed that nanofiber-based vaccines can be used to boost protection conferred by licensed vaccines like BCG. While combinations of peptide nanofibers and TLR agonists have proven to be effective inducers of humoral and cellular immunity, the synergy between their mechanisms of action has yet to be uncovered.

\subsection{Adaptive immune responses to PAs}

In the last decade, micelles and nanofibers composed of PAs have been utilized as vaccine carriers in a variety of disease models [152, 224-228]. Tirrell and coworkers reported a PA-based vaccine comprising $\mathrm{OVA}_{257-264}$ and dipalmitic acid that assembles into cylindrical micelles eight $\mathrm{nm}$ in diameter and typically between 50 and $300 \mathrm{~nm}$ in length [152]. In mice, these PAs triggered a robust $\mathrm{OVA}_{257-264}$-specific cytotoxic $\mathrm{T}$ cell response that reduced tumor burden without added adjuvants and was equivalent to OVA257-264 in incomplete Freund's adjuvant (IFA). The humoral immunogenicity of PAs was demonstrated using dipalmitic acid conjugated to J8, a B cell epitope derived from group A Streptococcus (GAS) bacteria [224]. Co-delivery (10 mol\%) with either the TLR2 agonist P2C-SK4 or the TLR4 agonist monophosphoryl lipid A (MPLA) further improved antibody titers. When J8dipalmitic acid peptide solutions were heated to anneal the assembled micelles, fibril lengths increased to two orders of magnitude larger than their width [225]. Without exogenous adjuvants, the annealed micelles elicited antibody levels comparable to unconjugated J8 in IFA. The protective efficacy of PA-based vaccines was confirmed in mice using the J14 GAS epitope [229-232].

Ulery and coworkers investigated the effect of incorporating a polyionic group into a PA containing $\mathrm{OVA}_{319-340}$ and mono- or dipalmitic acid [233, 234]. By altering the lipid tail number and the position of the $(\mathrm{EK})_{4}$ or $(\mathrm{KE})_{4}$ polyionic group, PA micelle morphology and size could be modulated to influence their immunogenicity [234]. Long fibrils assembled from molecules consisting of a single palmitic acid, an $\mathrm{OVA}_{319-340}$ epitope, and an intervening $(\mathrm{EK})_{4}$ moiety were unable to enter lymphatic vessels and produced virtually no IgG. When the polyionic head group of dipalmitic acid-containing PAs was varied between the positively charged $\mathrm{K}_{8}$, negatively charged $\mathrm{E}_{8}$, and zwitterionic $(\mathrm{KE})_{4}$ sequences, surface charge-dependent uptake of the micelles by APCs and preferential accumulation in the lymph nodes were observed.

Modifying PAs with the cell-penetrating Tat peptide facilitated internalization by APCs and upregulated MHC II and CD86, which enhanced vaccination outcomes in an influenza model [226]. Rather than directly attaching antigens, a PA displaying a C-terminal free biotin group was synthesized to capture biotinylated antigens via streptavidin linkers [235]. Using $\mathrm{OVA}_{257-264}$ as a model antigen, this approach improved cytokine release and cross-presentation in mice compared to OVA $257-264$ adjuvanted with CpG. Instead of lipid tails, micelles formed by PAs consisting of 3-diethylaminopropyl isothiocyanate (DEAP), a cleavable MMP-2 substrate, and a short D-peptide antagonist (DPPA-1) of programmed cell 
death ligand-1 were used to encapsulate an indoleamine 2,3-dioxygenase inhibitor [236]. In a melanoma model, treatment with these micelles amplified $\mathrm{CD} 8^{+} \mathrm{T}$ cell populations and subsequently slowed tumor growth, reducing overall mortality. Detailed biodistribution studies have concluded that PAs are generally non-cytotoxic and could be a promising avenue for the development of subunit vaccines and immunotherapies against infectious and non-infectious diseases [237, 238]. Non-lipidated PAs composed of a poly(hydrophobic amino acid) domain linked to a hydrophilic peptide have been used to preserve the conformation of conjugated antigens, which in some cases is necessary to elicit protective immunity against certain pathogens [239, 240]. Further, supramolecular lipopeptide-based vaccines incorporating non-natural amino acids have been shown to maintain structural integrity in harsh in vivo environments such as the mucosa, gut, and other biological barriers [241, 242].

\subsection{Adaptive immune responses to protein subunit nanoparticles}

Protein subunit nanoparticles are derived from natural (virus-, bacteria-, plant-, or animalderived) sources or designed de novo and lack the genetic material necessary for replication but otherwise resemble natural viruses. The multivalent nature of protein subunit nanoparticles and their ability to both encapsulate and deliver antigens makes them attractive for eliciting robust adaptive immunity, while their amenability to chemical functionalization avoids the antigen size limitations seen in some recombinant systems [159, 173, 243, 244]. Nanoparticles composed of virus- or bacteria-derived proteins can also activate PAMPs, which contribute to immunological memory [245]. Since the discovery of HBV protein VLPs in the sera of infected patients, nanoparticles derived from the surface antigen $\mathrm{HBsAg}$ or the core antigen $\mathrm{HBcAg}$ have been included in two licensed $\mathrm{HBV}$ vaccines (Engerix-B and Recombivax-HB) [82, 246]. Analogous protein nanoparticle vaccines containing recombinant HPV L1 major capsids that assemble into $\sim 50 \mathrm{~nm}$ virions have been approved as HPV prophylactics (Cervarix and Gardasil) [247, 248]. Carrier-induced immunosuppression can impede vaccine responses due to pre-existing immunity to viral proteins; however, chimeric $\mathrm{HBcAg}$ nanoparticles carrying human rhinovirus, malaria, and RSV epitopes effectively circumvent this phenomenon, potentially enabling vaccination against various diseases using identical carriers [249-252].

Molino et al. fabricated a caged protein structure consisting of 60 self-assembling units of the non-viral E2 core of pyruvate dehydrogenase linked to $\mathrm{CpG}$, which was used to encapsulate the model antigen $\mathrm{OVA}_{257-264}$ [253]. Treatment of DCs with the protein nanocages increased antigen presentation compared to soluble epitope and stimulated DC maturation, as evidenced by upregulated CD86 and MHC II. The effectiveness of E2 nanoparticles was confirmed using preclinical melanoma and HIV-1 vaccines [254-257]. Lee and coworkers have described nanocages derived from bacterial ferritin or the artificial cage protein I3-01 as carriers for the TLR5 agonist protein FliC or a truncated variant $(\triangle \mathrm{FliC})$ lacking the Naip5 inflammasome-activating domain D0, as well as protective antigen from Bacillus anthracis or influenza HA [258]. Mice vaccinated with HA- and $\Delta$ FliC-conjugated nanocages demonstrated $100 \%$ survival after H1N1 influenza challenge and clinical observations improved on par with the 2016-2017 quadrivalent inactivated influenza vaccine. An emerging strategy using bacteriophage coat protein $\mathrm{Q} \beta$ nanoparticles 
has been used in clinical trials as a nicotine hapten carrier to aid smoking cessation and as a delivery vehicle displaying the minimal epitope $\mathrm{A} \beta_{1-6}$ for Alzheimer's disease immunotherapy $[259,260]$. Protein subunit nanoparticle vaccines have also been applied to prevent influenza, HIV, norovirus, and SARS-CoV-2 [102, 261-263].

\section{Current challenges and future prospects}

Peptide-based supramolecular nanomaterials have demonstrated effectiveness as prophylactics and therapeutics to manipulate the immune system in multiple preclinical disease models; however, several unresolved challenges must be addressed if they are to be approved for clinical use. A key goal in the coming years will be to achieve vaccination efficacy approaching that of live attenuated or inactivated pathogens, which contain a broad spectrum of antigens and PRR agonists. The reductionist design of most subunit vaccines lack these broad antigenic and agonistic profiles, limiting their potency. Attaining specific three-dimensional structures is essential to eliciting neutralizing antibodies against some antigens; thus, delivery methods that conformationally stabilize these moieties are required. This is difficult to achieve using peptides, particularly those with $\beta$-sheet-rich architectures, as their length scales and morphologies are often heterogeneous and it remains a nontrivial task to preserve their structural integrity in vivo.

Numerous supramolecular peptide-based vaccines have been shown to stimulate adjuvantfree immune responses, but we have yet to elucidate the interactions between APCs and these multivalent structures and their influence on innate immunity, immunometabolism, B cell activation, and $\mathrm{T}$ cell memory formation. Emerging data on the combined effects of selfadjuvanting peptide nanomaterials and TLR agonists suggest that synergistic pathways may differentially activate TLRs, inflammasome signaling, autophagy, and T-independent B cell signaling. Moreover, functionally modifying supramolecular assemblies can further promote protective immunity by facilitating spatiotemporal control over antigen delivery, promoting high-affinity antigen-BCR or antigen-MHC interactions, maturation of APC function to boost costimulation, and augmentation of environmental signals that drive type-specific cytokine profiles.

Many of the vaccination platforms discussed in this review use OVA as a model antigen due to its reliably strong immunogenicity, availability of immunological reagents, and accessibility to transgenic animal repositories. While this enables us to investigate the evolution of immunological mechanisms, therapeutic outcomes observed in OVAbased pathogen or tumor models are not necessarily indicative of protection obtained using disease-relevant epitopes. Further, using large animal models such as rabbits, guinea pigs, ferrets, and non-human primates may accelerate translational efforts. Additionally, commercializing self-assembling peptide-based vaccines will require the continued development of cost-effective large-scale production that minimizes batch-tobatch variation. Despite this challenge, one self-assembling peptide has been accepted as a medical device by regulatory authorities, providing a precedent that may accelerate development and ease the approval of other supramolecular peptide systems. In particular, the RADA16 construct PuraStat is CE-marked as a class III device in the European Union, permitting its use as a hemostatic during surgery [264]. In the United States, a similar 
formulation is available in non-GMP forms for research purposes under the trade name PuraMatrix.

In summary, the development of supramolecular peptide-based immunomodulatory systems to prevent or treat disease holds great promise and warrants continued research to establish this emerging and versatile platform as a safe and effective alternative to current vaccines.

\section{Acknowledgments}

This work was supported by Washington University in St. Louis Department of Biomedical Engineering, the National Institute of Allergy and Infectious Diseases [R01 AI130278-01A 1] and the National Institute on Drug Abuse [1 R21 DA036663-01].

\section{References}

[1]. Lahariya C, Vaccine epidemiology: a review, J. Fam. Med. Prim. Care. 5 (2016) 7-15.

[2]. Cable J, Srikantiah P, Crowe JE, Pulendran B, Hill A, Ginsberg A, Koff W, Mathew A, Ng T, Jansen K, Glenn G, Permar S, Wilson I, Weiner DB, Weissman D, Rappuoli R, Vaccine innovations for emerging infectious diseases-A symposium report, Ann. N. Y. Acad. Sci 1462 (2020) 14-26. [PubMed: 31659752]

[3]. United States Food and Drug Administration, Vaccines licensed for use in the US, (2020).). https:// www.fda.gov/vaccines-blood-biologics/vaccines/vaccines-licensed-use-united-states/ (accessed January 31, 2021).

[4]. Vetter V, Denizer G, Friedland LR, Krishnan J, Shapiro M, Understanding modern-day vaccines: what you need to know, Ann. Med. 50 (2018) 110-120. [PubMed: 29172780]

[5]. Villarreal R, Casale TB, Commonly used adjuvant human vaccines: advantages and side effects, J. Allergy Clin. Immunol. Pract. 8 (2020) 2953-2957. [PubMed: 32360184]

[6]. Hubbell JA, Thomas SN, Swartz MA, Materials engineering for im munomodulation, Nature 462 (2009) 449-460. [PubMed: 19940915]

[7]. Hotaling NA, Tang L, Irvine DJ, Babensee JE, Biomaterial strategies for im munomodulation, Annu. Rev. Biomed. Eng. 17 (2015) 317-349. [PubMed: 26421896]

[8]. Sahoo JK, Braegelman AS, Webber MJ, Immunoengineering with supramolecular peptide biomaterials, J. Indian Inst. Sci. 98 (2018) 69-79.

[9]. Zhao G, Chandrudu S, Skwarczynski M, Toth I, The application of self--assembled nanostructures in peptide-based subunit vaccine development, Eur. Polym. J. 93 (2017) 670-681. [PubMed: 32226094]

[10]. Eppler HB, Jewell CM, Biomaterials as tools to decode immunity, Adv. Mater. 32 (2020) 1903367.

[11]. Dellacherie MO, Seo BR, Mooney DJ, Macroscale biomaterials strategies for local immunomodulation, Nat. Rev. Mater. 4 (2019) 379-397.

[12]. Mart RJ, Osborne RD, Stevens MM, Ulijn RV, Peptide-based stimuli-responsive biomaterials, Soft Matter 2 (2006) 822-835. [PubMed: 32680274]

[13]. Mandal D, Nasrolahi Shirazi A, Parang K, Self-assembly of peptides to nanostructures, Org. Biomol. Chem. 12 (2014) 3544-3561. [PubMed: 24756480]

[14]. Zacco E, Anish C, Martin CE, Berlepsch HV, Brandenburg E, Seeberger PH, Koksch B, A self-assembling peptide scaffold for the multivalent presentation of antigens, Biomacromolecules 16 (2015) 2188-2197. [PubMed: 26017366]

[15]. Woolfson DN, The design of coiled-coil structures and assemblies, Adv. Protein Chem. 70 (2005) 79-112. [PubMed: 15837514]

[16]. Wu Y, Collier JH, a-Helical coiled-coil peptide materials for biomedical applications, Wiley Interdiscip. Rev. Nanomed. Nanobiotechnol. 9 (2017) e1424. 
[17]. Kreitler DF, Yao Z, Steinkruger JD, Mortenson DE, Huang L, Mittal R, Travis BR, Forest KT, Gellman SH, A hendecad motif is preferred for heterochiral coiled-coil formation, J. Am. Chem. Soc. 141 (2019) 1583-1592. [PubMed: 30645104]

[18]. Hicks MR, Holberton DV, Kowalczyk C, Woolfson DN, Coiled-coil assembly by peptides with non-heptad sequence motifs, Fold. Des. 2 (1997) 149-158. [PubMed: 9218952]

[19]. Parry DAD, Hendecad repeat in segment 2A and linker L2 of intermediate filament chains implies the possibility of a right-handed coiled-coil structure, J. Struct. Biol. 155 (2006) 370 374. [PubMed: 16713299]

[20]. Harbury PB, Zhang T, Kim PS, Alber T, A switch between two-, three-, and four-stranded coiled coils in GCN4 leucine zipper mutants, Science 262 (1993) 1401-1407. [PubMed: 8248779]

[21]. Liu J, Yong W, Deng Y, Kallenbach NR, Lu M, Atomic structure of a tryptophan-zipper pentamer, Proc. Natl. Acad. Sci. U.S.A. 101 (2004) 16156-16161. [PubMed: 15520380]

[22]. Liu J, Zheng Q, Deng Y, Cheng CS, Kallenbach NR, Lu M, A seven-helix coiled coil, Proc. Natl. Acad. Sci. U.S.A. 103 (2006) 15457-15462. [PubMed: 17030805]

[23]. Lumb KJ, Kim PS, A buried polar interaction imparts structural uniqueness in a designed heterodimeric coiled coil, Biochemistry 34 (1995) 8642-8648. [PubMed: 7612604]

[24]. McClain DL, Woods HL, Oakley MG, Design and characterization of a heterodimeric coiled coil that forms exclusively with an antiparallel relative helix orientation, J. Am. Chem. Soc. 123 (2001) 3151-3152. [PubMed: 11457033]

[25]. Gurnon DG, Whitaker JA, Oakley MG, Design and characterization of a homodimeric antiparallel coiled coil, J. Am. Chem. Soc. 125 (2003) 7518-7519. [PubMed: 12812483]

[26]. Egelman EH, Xu C, DiMaio F, Magnotti E, Modlin C, Yu X, Wright E, Baker D, Conticello VP, Structural plasticity of helical nanotubes based on coiled-coil assemblies, Structure 23 (2015) 280-289. [PubMed: 25620001]

[27]. Raman S, Machaidze G, Lustig A, Aebi U, Burkhard P, Structure-based design of peptides that self-assemble into regular polyhedral nanoparticles, Nanomedicine 2 (2006) 95-102. [PubMed: 17292121]

[28]. Kaba SA, Brando C, Guo Q, Mittelholzer C, Raman S, Tropel D, Aebi U, Burkhard P, Lanar DE, A nonadjuvanted polypeptide nanoparticle vaccine confers long-lasting protection against rodent malaria, J. Immunol. 183 (2009) 7268-7277. [PubMed: 19915055]

[29]. Kaba SA, Karch CP, Seth L, Ferlez KMB, Storme CK, Pesavento DM, Laughlin PY, BergmannLeitner ES, Burkhard P, Lanar DE, Self-assembling protein nanoparticles with built-in flagellin domains increases protective efficacy of a Plasmodium falciparum based vaccine, Vaccine 36 (2018) 906-914. [PubMed: 29269157]

[30]. Fletcher JM, Harniman RL, Barnes FRH, Boyle AL, Collins A, Mantell J, Sharp TH, Antognozzi M, Booth PJ, Linden N, Miles MJ, Sessions RB, Verkade P, Woolfson DN, Self-assembling cages from coiled-coil peptide modules, Science 340 (2013) 595-599. [PubMed: 23579496]

[31]. Fletcher JM, Boyle AL, Bruning M, Bartlett GJ, Vincent TL, Zaccai NR, Armstrong CT, Bromley EHC, Booth PJ, Brady RL, Thomson AR, Woolfson DN, A basis set of de novo coiled-coil peptide oligomers for rational protein design and synthetic biology, ACS Synth. Biol. 1 (2012) 240-250. [PubMed: 23651206]

[32]. Boato F, Thomas RM, Ghasparian A, Freund-Renard A, Moehle K, Robinson JA, Synthetic virus-like particles from self-assembling coiled-coil lipopeptides and their use in antigen display to the immune system, Angew. Chemie Int. Ed. 46 (2007) 9015-9018.

[33]. Burkhard P, Kammerer RA, Steinmetz MO, Bourenkov GP, Aebi U, The coiled-coil trigger site of the rod domain of cortexillin I unveils a distinct network of interhelical and intrahelical salt bridges, Structure 8 (2000) 223-230. [PubMed: 10745004]

[34]. Wu Y, Norberg PK, Reap EA, Congdon KL, Fries CN, Kelly SH, Sampson JH, Conticello VP, Collier JH, A supramolecular vaccine platform based on a-helical peptide nanofibers, ACS Biomater. Sci. Eng. 3 (2017) 3128-3132. [PubMed: 30740520]

[35]. Richardson JS, $\beta$-Sheet topology and the relatedness of proteins, Nature 268 (1977) 495-500. [PubMed: 329147] 
[36]. Moore AN, Hartgerink JD, Self-assembling multidomain peptide nanofibers for delivery of bioactive molecules and tissue regeneration, Acc. Chem. Res. 50 (2017) 714-722. [PubMed: 28191928]

[37]. Hartgerink JD, Beniash E, Stupp SI, Self-assembly and mineralization of peptide-amphiphile nanofibers, Science 294 (2001) 1684-1689. [PubMed: 11721046]

[38]. Beesley JL, Baum HE, Hodgson LR, Verkade P, Banting GS, Woolfson DN, Modifying selfassembled peptide cages to control internalization into mammalian cells, Nano Lett. 18 (2018) 5933-5937. [PubMed: 30084257]

[39]. Pauling L, Corey RB, Configurations of polypeptide chains with favored orientations around single bonds: two new pleated sheets, Proc. Natl. Acad. Sci. U.S.A. 37 (1951) 729-740. [PubMed: 16578412]

[40]. Chothia C, Levitt M, Richardson D, Structure of proteins: packing of a-helices and pleated sheets, Proc. Natl. Acad. Sci. U.S.A. 74 (1977) 4130-4134. [PubMed: 270659]

[41]. Chou KC, Pottle M, Némethy G, Ueda Y, Scheraga HA, Structure of $\beta$-sheets: origin of the right-handed twist and of the increased stability of antiparallel over parallel sheets, J. Mol. Biol. 162 (1982) 89-112. [PubMed: 7154095]

[42]. Quinn TP, Tweedy NB, Williams RW, Richardson JS, Richardson DC, Betadoublet: de novo design, synthesis, and characterization of a $\beta$-sandwich protein, Proc. Natl. Acad. Sci. U.S.A. 91 (1994) 8747-8751. [PubMed: 8090717]

[43]. Chou PY, Fasman GD, Conformational parameters for amino acids in helical, $\beta$-sheet, and random coil regions calculated from proteins, Biochemistry 13 (1974) 211-222. [PubMed: 4358939]

[44]. Kim CA, Berg JM, Thermodynamic $\beta$-sheet propensities measured using a zinc-finger host peptide, Nature 362 (1993) 267-270. [PubMed: 8459852]

[45]. King IC, Gleixner J, Doyle L, Kuzin A, Hunt JF, Xiao R, Montelione GT, Stoddard BL, DiMaio F, Baker D, Precise assembly of complex beta sheet topologies from de novo designed building blocks, Elife 4 (2015) e11012. [PubMed: 26650357]

[46]. Hamley IW, Peptide fibrillization, Angew. Chemie Int. Ed. 46 (2007) 8128-8147.

[47]. Goldschmidt L, Teng PK, Riek R, Eisenberg D, Identifying the amylome, proteins capable of forming amyloid-like fibrils, Proc. Natl. Acad. Sci. U.S.A. 107 (2010) 3487-3492. [PubMed: 20133726]

[48]. Mandel-Gutfreund Y, Gregoret LM, On the significance of alternating patterns of polar and non-polar residues in beta-strands, J. Mol. Biol. 323 (2002) 453-461. [PubMed: 12381301]

[49]. Fishwick CWG, Beevers AJ, Carrick LM, Whitehouse CD, Aggeli A, Boden N, Structures of helical $\beta$-tapes and twisted ribbons: the role of side-chain interactions on twist and bend behavior, Nano Lett 3 (2003) 1475-1479.

[50]. Pantoja-Uceda D, Santiveri CM, Jiménez MA, De novo design of monomeric $\beta$-hairpin and $\beta$-sheet peptides, Methods Mol. Biol. 340 (2006) 27-51. [PubMed: 16957331]

[51]. Rughani RV, Salick DA, Lamm MS, Yucel T, Pochan DJ, Schneider JP, Fold ing, selfassembly, and bulk material properties of a de novo designed three--stranded $\beta$-sheet hydrogel, Biomacromolecules 10 (2009) 1295-1304. [PubMed: 19344123]

[52]. Davies RPW, Aggeli A, Self-assembly of amphiphilic $\beta$-sheet peptide tapes based on aliphatic side chains, J. Pept. Sci. 17 (2011) 107-114. [PubMed: 21234982]

[53]. Seroski DT, Dong X, Wong KM, Hudalla GA, Charge guides pathway selection in $\beta$-sheet fibrillizing peptide co-assembly, Commun. Chem. 3 (2020) 1-11.

[54]. Gazit E, A possible role for $\pi$-stacking in the self-assembly of amyloid fibrils, FASEB J. 16 (2002) 77-83. [PubMed: 11772939]

[55]. Biancalana M, Makabe K, Koide A, Koide S, Aromatic cross-strand ladders control the structure and stability of $\beta$-rich peptide self-assembly mimics, J. Mol. Biol. 383 (2008) 205-213. [PubMed: 18762191]

[56]. Zhang S, Holmes T, Lockshin C, Rich A, Spontaneous assembly of a self-complementary oligopeptide to form a stable macroscopic membrane, Proc. Natl. Acad. Sci. U.S.A. 90 (1993) 3334-3338. [PubMed: 7682699] 
[57]. Yokoi H, Kinoshita T, Zhang S, Dynamic reassembly of peptide RADA16 nanofiber scaffold, Proc. Natl. Acad. Sci. U.S.A. 102 (2005) 8414-8419. [PubMed: 15939888]

[58]. Leon EJ, Verma N, Zhang S, Lauffenburger DA, Kamm RD, Mechanical properties of a selfassembling oligopeptide matrix, J. Biomater. Sci. Polym. Ed. 9 (1998) 297-312. [PubMed: 9556763]

[59]. Marini DM, Hwang W, Lauffenburger DA, Zhang S, Kamm RD, Left-handed helical ribbon intermediates in the self-assembly of a $\beta$-sheet peptide, Nano Lett. 2 (2002) 295-299.

[60]. Caplan MR, Schwartzfarb EM, Zhang S, Kamm RD, Lauffenburger DA, Control of selfassembling oligopeptide matrix formation through systematic variation of amino acid sequence, Biomaterials 23 (2002) 219-227. [PubMed: 11762841]

[61]. Collier JH, Messersmith PB, Enzymatic modification of self-assembled peptide structures with tissue transglutaminase, Bioconjug. Chem. 14 (2003) 748-755. [PubMed: 12862427]

[62]. Schneider JP, Pochan DJ, Ozbas B, Rajagopal K, Pakstis L, Kretsinger J, Responsive hydrogels from the intramolecular folding and self-assembly of a designed peptide, J. Am. Chem. Soc. 124 (2002) 15030-15037. [PubMed: 12475347]

[63]. Bowerman CJ, Ryan DM, Nissan DA, Nilsson BL, The effect of increasing hydrophobicity on the self-assembly of amphipathic $\beta$-sheet peptides, Mol. Biosyst. 5 (2009) 1058-1069. [PubMed: 19668872]

[64]. Bowerman CJ, Liyanage W, Federation AJ, Nilsson BL, Tuning $\beta$-sheet peptide self-assembly and hydrogelation behavior by modification of sequence hydrophobicity and aromaticity, Biomacromolecules 12 (2011) 2735-2745. [PubMed: 21568346]

[65]. Hong Y, Legge RL, Zhang S, Chen P, Effect of amino acid sequence and $\mathrm{pH}$ on nanofiber formation of self-assembling peptides EAK16-II and EAK16-IV, Biomacromolecules 4 (2003) 1433-1442. [PubMed: 12959616]

[66]. Zhang S, Altman M, Peptide self-assembly in functional polymer science and engineering, React. Funct. Polym. 41 (1999) 91-102.

[67]. Lee NR, Bowerman CJ, Nilsson BL, Sequence length determinants for self-assembly of amphipathic $\beta$-sheet peptides, Biopolymers 100 (2013) 738-750. [PubMed: 23553562]

[68]. Kyle S, Aggeli A, Ingham E, McPherson MJ, Recombinant self-assembling peptides as biomaterials for tissue engineering, Biomaterials 31 (2010) 9395-9405. [PubMed: 20932572]

[69]. Haines-Butterick L, Rajagopal K, Branco M, Salick D, Rughani R, Pilarz M, Lamm MS, Pochan DJ, Schneider JP, Controlling hydrogelation kinetics by peptide design for three-dimensional encapsulation and injectable delivery of cells, Proc. Natl. Acad. Sci. U.S.A. 104 (2007) 77917796. [PubMed: 17470802]

[70]. Yu YC, Berndt P, Tirrell M, Fields GB, Self-assembling amphiphiles for construction of protein molecular architecture, J. Am. Chem. Soc. 118 (1996) 12515-12520.

[71]. Berndt P, Fields GB, Tirrell M, Synthetic lipidation of peptides and amino acids: monolayer structure and properties, J. Am. Chem. Soc. 117 (1995) 9515-9522.

[72]. Cui H, Webber MJ, Stupp SI, Self-assembly of peptide amphiphiles: from molecules to nanostructures to biomaterials, Biopolymers 94 (2010) 1-18. [PubMed: 20091874]

[73]. Paramonov SE, Jun HW, Hartgerink JD, Self-assembly of peptide-amphiphile nanofibers: the roles of hydrogen bonding and amphiphilic packing, J. Am. Chem. Soc. 128 (2006) 7291-7298. [PubMed: 16734483]

[74]. Stendahl JC, Rao MS, Guler MO, Stupp SI, Intermolecular forces in the self-assembly of peptide amphiphile nanofibers, Adv. Funct. Mater. 16 (2006) 499-508.

[75]. Cui H, Cheetham AG, Pashuck ET, Stupp SI, Amino acid sequence in constitutionally isomeric tetrapeptide amphiphiles dictates architecture of one-dimensional nanostructures, J. Am. Chem. Soc. 136 (2014) 12461-12468. [PubMed: 25144245]

[76]. Hartgerink JD, Beniash E, Stupp SI, Peptide-amphiphile nanofibers: a versatile scaffold for the preparation of self-assembling materials, Proc. Natl. Acad. Sci. U.S.A. 99 (2002) 5133-5138. [PubMed: 11929981]

[77]. Pashuck ET, Cui H, Stupp SI, Tuning supramolecular rigidity of peptide fibers through molecular structure, J. Am. Chem. Soc. 132 (2010) 6041-6046. [PubMed: 20377229] 
[78]. Bachmann MF, Jennings GT, Vaccine delivery: a matter of size, geometry, kinetics and molecular patterns, Nat. Rev. Immunol. 10 (2010) 787-796. [PubMed: 20948547]

[79]. Matsuura K, Synthetic approaches to construct viral capsid-like spherical nanomaterials, Chem. Commun. 54 (2018) 8944-8959.

[80]. Prasad BVV, Schmid MF, Principles of virus structural organisation, Adv. Exp. Med. Biol. 726 (2012) 17-47. [PubMed: 22297509]

[81]. Takahashi WN, Ishii M, An abnormal protein associated with tobacco mosaic virus infection, Nature 169 (1952) 419-420. [PubMed: 14919589]

[82]. López-Sagaseta J, Malito E, Rappuoli R, Bottomley MJ, Self-assembling protein nanoparticles in the design of vaccines, Comput. Struct. Biotechnol. J. 14 (2016) 58-68. [PubMed: 26862374]

[83]. Frietze KM, Peabody DS, Chackerian B, Engineering virus-like particles as vaccine platforms, Curr. Opin. Virol. 18 (2016) 44-49. [PubMed: 27039982]

[84]. Syomin BV, Ilyin YV, Virus-like particles as an instrument of vaccine production, Mol. Biol. 53 (2019) 323-334. [PubMed: 32214478]

[85]. de la Cruz VF, Lal AA, McCutchan TF, Immunogenicity and epitope mapping of foreign sequences via genetically engineered filamentous phage, J. Biol. Chem. 263 (1988) 4318-4322. [PubMed: 2450091]

[86]. Burns NR, Saibil HR, White NS, Pardon JF, Timmins PA, Richardson SM, Richards BM, Adams SE, Kingsman SM, Kingsman AJ, Symmetry, flexibility and permeability in the structure of yeast retrotransposon virus-like particles, EMBO J. 11 (1992) 1155-1164. [PubMed: 1312462]

[87]. Clarke BE, Newton SE, Carroll AR, Francis MJ, Appleyard G, Syred AD, Highfield PE, Rowlands DJ, Brown F, Improved immunogenicity of a peptide epitope after fusion to hepatitis B core protein, Nature 330 (1987) 381-384. [PubMed: 2446137]

[88]. Brown CS, Welling-Wester S, Feijlbrief M, van Lent JWM, Spaan WJM, Chimeric parvovirus B19 capsids for the presentation of foreign epitopes, Virology 198 (1994) 477-488. [PubMed: 7507280]

[89]. Hwang DJ, Roberts IM, Wilson TM, Expression of tobacco mosaic virus coat protein and assembly of pseudovirus particles in Escherichia coli, Proc. Natl. Acad. Sci. U.S.A. 91 (1994) 9067-9071. [PubMed: 8090770]

[90]. Yeates TO, Jacobson DH, Martin A, Wychowski C, Girard M, Filman DJ, Hogle JM, Threedimensional structure of a mouse-adapted type 2/type 1 poliovirus chimera, EMBO J. 10 (1991) 2331-2341. [PubMed: 1651227]

[91]. Sabara M, Parker M, Aha P, Cosco C, Gibbons E, Parsons S, Babiuk LA, Assembly of doubleshelled rotaviruslike particles by simultaneous expression of recombinant VP6 and VP7 proteins, J. Virol. 65 (1991) 6994-6997. [PubMed: 1658389]

[92]. Urakawa T, Ferguson M, Minor PD, Cooper J, Sullivan M, Almond JW, Bishop DHL, Synthesis of immunogenic, but non-infectious, poliovirus particles in insect cells by a baculovirus expression vector, J. Gen. Virol. 70 (1989) 1453-1463. [PubMed: 2543785]

[93]. Thomsen DR, Roof LL, Homa FL, Assembly of herpes simplex virus (HSV) intermediate capsids in insect cells infected with recombinant baculoviruses expressing HSV capsid proteins, J. Virol. 68 (1994) 2442-2457. [PubMed: 8139029]

[94]. Casal JI, Rueda P, Hurtado A, Parvovirus-like particles as vaccine vectors, Methods 19 (1999) 174-186. [PubMed: 10525454]

[95]. Lee LA, Wang Q, Adaptations of nanoscale viruses and other protein cages for medical applications, Nanomedicine 2 (2006) 137-149. [PubMed: 17292136]

[96]. Kanekiyo M, Wei CJ, Yassine HM, McTamney PM, Boyington JC, Whittle JRR, Rao SS, Kong WP, Wang L, Nabel GJ, Self-assembling influenza nanoparticle vaccines elicit broadly neutralizing H1N1 antibodies, Nature 499 (2013) 102-106. [PubMed: 23698367]

[97]. Darricarrère N, Pougatcheva S, Duan X, Rudicell RS, Chou T-H, DiNapoli J, Ross TM, Alefantis T, Vogel TU, Kleanthous H, Wei C-J, Nabel GJ, Development of a pan-H1 influenza vaccine, J. Virol. (2018) 92.

[98]. Abbott RK, Lee JH, Menis S, Skog P, Rossi M, Ota T, Kulp DW, Bhullar D, Kalyuzhniy O, Havenar-Daughton C, Schief WR, Nemazee D, Crotty S, Pre-cursor frequency and affinity 
determine B cell competitive fitness in germinal centers, tested with germline-targeting HIV vaccine immunogens, Immunity 48 (2018) 133-146. [PubMed: 29287996]

[99]. Kanekiyo M, Bu W, Joyce MG, Meng G, Whittle JRR, Baxa U, Yamamoto T, Narpala S, Todd J-P, Rao SS, McDermott AB, Koup RA, Rossmann MG, Mascola JR, Graham BS, Cohen JI, Nabel GJ, Rational design of an Epstein-Barr virus vaccine targeting the receptor-binding site, Cell 162 (2015) 1090-1100. [PubMed: 26279189]

[100]. Ueda G, Antanasijevic A, Fallas JA, Sheffler W, Copps J, Ellis D, Hutchinson GB, Moyer A, Yasmeen A, Tsybovsky Y, Park YJ, Bick MJ, Sankaran B, Gillespie RA, Brouwer PJM, Zwart PH, Veesler D, Kanekiyo M, Graham BS, Sanders RW, Moore JP, Klasse PJ, Ward AB, King NP, Baker D, Tailored design of protein nanoparticle scaffolds for multivalent presentation of viral glycoprotein antigens, Elife 9 (2020) e57659. [PubMed: 32748788]

[101]. Bale JB, Gonen S, Liu Y, Sheffler W, Ellis D, Thomas C, Cascio D, Yeates TO, Gonen T, King NP, Baker D, Accurate design of megadalton-scale two-component icosahedral protein complexes, Science 353 (2016) 389-394. [PubMed: 27463675]

[102]. Walls AC, Fiala B, Schäfer A, Wrenn S, Pham MN, Murphy M, Tse LV, Shehata L, O'Connor MA, Chen C, Navarro MJ, Miranda MC, Pettie D, Ravichandran R, Kraft JC, Ogohara C, Palser A, Chalk S, Lee EC, Guerriero K, Kepl E, Chow CM, Sydeman C, Hodge EA, Brown B, Fuller JT, Dinnon KH, Gralinski LE, Leist SR, Gully KL, Lewis TB, Guttman M, Chu HY, Lee KK, Fuller DH, Baric RS, Kellam P, Carter L, Pepper M, Sheahan TP, Veesler D, King NP, Elicitation of potent neutralizing antibody responses by designed protein nanoparticle vaccines for SARS-CoV-2, Cell 183 (2020) 1367-1382. [PubMed: 33160446]

[103]. Oyewumi MO, Kumar A, Cui Z, Nano-microparticles as immune adjuvants: correlating particle sizes and the resultant immune responses, Expert Rev. Vaccines. 9 (2010) 1095-1107. [PubMed: 20822351]

[104]. Rajagopal K, Schneider JP, Self-assembling peptides and proteins for nanotechnological applications, Curr. Opin. Struct. Biol. 14 (2004) 480-486. [PubMed: 15313243]

[105]. Drexler KE, Molecular engineering: an approach to the development of general capabilities for molecular manipulation, Proc. Natl. Acad. Sci. U.S.A. 78 (1981) 5275-5278. [PubMed: 16593078]

[106]. Batista FD, Harwood NE, The who, how and where of antigen presentation to B cells, Nat. Rev. Immunol. 9 (2009) 15-27. [PubMed: 19079135]

[107]. Rahman AH, Taylor DK, Turka LA, The contribution of direct TLR signaling to T cell responses, Immunol. Res. 45 (2009) 25-36. [PubMed: 19597998]

[108]. Kawai T, Akira S, The role of pattern-recognition receptors in innate immunity: update on Toll-like receptors, Nat. Immunol. 11 (2010) 373-384. [PubMed: 20404851]

[109]. Tang D, Kang R, Coyne CB, Zeh HJ, Lotze MT, PAMPs and DAMPs: signal 0 s that spur autophagy and immunity, Immunol. Rev. 249 (2012) 158-175. [PubMed: 22889221]

[110]. Takeuchi O, Akira S, Pattern recognition receptors and inflammation, Cell 140 (2010) 805-820. [PubMed: 20303872]

[111]. Blasius AL, Beutler B, Intracellular Toll-like receptors, Immunity 32 (2010) 305-315. [PubMed: 20346772]

[112]. Takeuchi O, Hoshino K, Kawai T, Sanjo H, Takada H, Ogawa T, Takeda K, Akira S, Differential roles of TLR2 and TLR4 in recognition of gram-negative and gram-positive bacterial cell wall components, Immunity 11 (1999) 443-451. [PubMed: 10549626]

[113]. Applequist SE, Rollman E, Wareing MD, Lidén M, Rozell B, Hinkula J, Ljunggren H-G, Activation of innate immunity, inflammation, and potentiation of DNA vaccination through mammalian expression of the TLR5 agonist flagellin, J. Immunol. 175 (2005) 3882-3891. [PubMed: 16148134]

[114]. Dowling DJ, Recent advances in the discovery and delivery of TLR7/8 agonists as vaccine adjuvants, ImmunoHorizons 2 (2018) 185-197. [PubMed: 31022686]

[115]. Ribas A, Medina T, Kummar S, Amin A, Kalbasi A, Drabick JJ, Barve M, Daniels GA, Wong DJ, Schmidt EV, Candia AF, Coffman RL, Leung ACF, Janssen RS, SD-101 in combination with pembrolizumab in advanced melanoma: results of a phase Ib, multicenter study, Cancer Discov. 8 (2018) 1250-1257. [PubMed: 30154193] 
[116]. Otsuka T, Nishida S, Hamaguchi M, Shibahara T, Shiroyama T, Kimura K, Hirata H, Kida H, Ishii KJ, Kumanogoh A, Phase I study of CpG ODN(K3), a novel Toll-like receptor 9 agonist, for advanced lung cancer: interim analyses of safety and immunity in subcutaneous injection cohort, J. Clin. Oncol. 37 (2019) 126.

[117]. Coler RN, Day TA, Ellis R, Piazza FM, Beckmann AM, Vergara J, Rolf T, Lu L, Alter G, Hokey D, Jayashankar L, Walker R, Snowden MA, Evans T, Ginsberg A, Reed SG, The TLR-4 agonist adjuvant, GLA-SE, improves magnitude and quality of immune responses elicited by the ID93 tuberculosis vaccine: first-in-human trial, NPJ Vaccines 3 (2018) 1-9. [PubMed: 29354293]

[118]. Carter D, van Hoeven N, Baldwin S, Levin Y, Kochba E, Magill A, Charland N, Landry N, Nu K, Frevol A, Ashman J, Sagawa ZK, Beckmann AM, Reed SG, The adjuvant GLA-AF enhances human intradermal vaccine responses, Sci. Adv. 4 (2018) 9930.

[119]. Gao H-X, Bhattacharya S, Matheny CJ, Yanamandra N, Zhang S-Y, Emerich H, Li Y, Bojczuk P, Shi H, Wang W, Hopson C, Fu T, Allison JP, Sharma P, Smothers JF, Srinivasan R, Hoos A, Synergy of TLR4 agonist GSK1795091, an innate immune activator, with agonistic antibody against co-stimulatory immune checkpoint molecule OX40 in cancer immunotherapy, J. Clin. Oncol. 36 (2018) 12055-12055.

[120]. Duthie MS, Windish HP, Fox CB, Reed SG, Use of defined TLR ligands as adjuvants within human vaccines, Immunol. Rev. 239 (2011) 178-196. [PubMed: 21198672]

[121]. Anwar MA, Shah M, Kim J, Choi S, Recent clinical trends in Toll-like receptor targeting therapeutics, Med. Res. Rev. 39 (2019) 1053-1090. [PubMed: 30450666]

[122]. Geginat J, Paroni M, Maglie S, Alfen JS, Kastirr I, Gruarin P, De Simone M, Pagani M, Abrignani S, Plasticity of human CD4 T cell subsets, Front. Immunol. 5 (2014) 630. [PubMed: 25566245]

[123]. Kratky W, e Sousa CR, Oxenius A, Spörri R, Direct activation of antigen-presenting cells is required for CD8+ T-cell priming and tumor vaccination, Proc. Natl. Acad. Sci. U.S.A. 108 (2011) 17414-17419. [PubMed: 21987815]

[124]. Tripp R, Role of cytokines in the development and maintenance of memory T cells during respiratory viral infection, Curr. Pharm. Des. 9 (2005) 51-59.

[125]. Gasper DJ, Tejera MM, Suresh M, CD4 T-cell memory generation and maintenance, Crit. Rev. Immunol. 34 (2014) 121-146. [PubMed: 24940912]

[126]. Farber DL, Yudanin NA, Restifo NP, Human memory T cells: generation, compartmentalization and homeostasis, Nat. Rev. Immunol. 14 (2014) 24-35. [PubMed: 24336101]

[127]. Pennock ND, White JT, Cross EW, Cheney EE, Tamburini BA, Kedl RM, T cell responses: naïve to memory and everything in between, Adv. Physiol. Educ. 37 (2013) 273-283. [PubMed: 24292902]

[128]. Chaplin DD, Overview of the immune response, J. Allergy Clin. Immunol. 125 (2010) S3-S23. [PubMed: 20176265]

[129]. Snapper CM, Distinct immunologic properties of soluble versus particulate antigens, Front. Immunol. 9 (2018) 598. [PubMed: 29619034]

[130]. Wu Y, Kelly SH, Sanchez-Perez L, Sampson JH, Collier JH, Comparative study of a-helical and $\beta$-sheet self-assembled peptide nanofiber vaccine platforms: influence of integrated T-cell epitopes, Biomater. Sci. 8 (2020) 3522-3535. [PubMed: 32452474]

[131]. Si Y, Wen Y, Chen J, Pompano RR, Han H, Collier JH, Chong AS, MyD88 in antigenpresenting cells is not required for CD4+ T-cell responses during peptide nanofiber vaccination, MedChemComm 9 (2018) 138-148. [PubMed: 29629068]

[132]. Wen Y, Waltman A, Han H, Collier JH, Switching the immunogenicity of peptide assemblies using surface properties, ACS Nano 10 (2016) 9274-9286. [PubMed: 27680575]

[133]. Chen J, Pompano RR, Santiago FW, Maillat L, Sciammas R, Sun T, Han H, Topham DJ, Chong AS, Collier JH, The use of self-adjuvanting nanofiber vaccines to elicit high-affinity B cell responses to peptide antigens without inflammation, Biomaterials 34 (2013) 8776-8785. [PubMed: 23953841]

[134]. Li X, Wang Y, Wang S, Liang C, Pu G, Chen Y, Wang L, Xu H, Shi Y, Yang Z, A strong CD8+ T cell-stimulating supramolecular hydrogel, Nanoscale 12 (2020) 2111-2117. [PubMed: 31913398] 
[135]. Rudra JS, Khan A, Clover TM, Endsley JJ, Zloza A, Wang J, Jagannath C, Supramolecular peptide nanofibers engage mechanisms of autophagy in antigen-presenting cells, ACS Omega 2 (2017) 9136-9143. [PubMed: 29302635]

[136]. Münz C, Autophagy proteins in antigen processing for presentation on MHC molecules, Immunol. Rev. 272 (2016) 17-27. [PubMed: 27319339]

[137]. Jagannath C, Lindsey DR, Dhandayuthapani S, Xu Y, Hunter RL, Eissa NT, Autophagy enhances the efficacy of BCG vaccine by increasing peptide presentation in mouse dendritic cells, Nat. Med. 15 (2009) 267-276. [PubMed: 19252503]

[138]. Nixon RA, The role of autophagy in neurodegenerative disease, Nat. Med. 19 (2013) 983-997. [PubMed: 23921753]

[139]. Bodani RU, Sengupta U, Castillo-Carranza DL, Guerrero-Muñoz MJ, Gerson JE, Rudra J, Kayed R, Antibody against small aggregated peptide specifically recognizes toxic A $\beta-42$ oligomers in Alzheimer's disease, ACS Chem. Neurosci. 6 (2015) 1981-1989. [PubMed: 26448453]

[140]. Chesson CB, Huante M, Nusbaum RJ, Walker AG, Clover TM, Chinnaswamy J, Endsley JJ, Rudra JS, Nanoscale peptide self-assemblies boost BCG-primed cellular immunity against Mycobacterium tuberculosis, Sci. Rep. 8 (2018) 1-14. [PubMed: 29311619]

[141]. Zhou J, Du X, Li J, Yamagata N, Xu B, Taurine boosts cellular uptake of small D-peptides for enzyme-instructed intracellular molecular self-assembly, J. Am. Chem. Soc. 137 (2015) 1004010043. [PubMed: 26235707]

[142]. Gao Y, Shi J, Yuan D, Xu B, Imaging enzyme-triggered self-assembly of small molecules inside live cells, Nat. Commun. 3 (2012) 1033. [PubMed: 22929790]

[143]. Zhou J, Du X, Chen X, Wang J, Zhou N, Wu D, Xu B, Enzymatic self-assembly confers exceptionally strong synergism with NF- $\kappa \mathrm{B}$ targeting for selective necroptosis of cancer cells, $\mathrm{J}$. Am. Chem. Soc. 140 (2018) 2301-2308. [PubMed: 29377688]

[144]. Xu Y, Wang Y, Yang Q, Liu Z, Xiao Z, Le Z, Yang Z, Yang C, A versatile supramolecular nanoadjuvant that activates NF- $\kappa$ B for cancer immunotherapy, Theranostics 9 (2019) 3388-3397. [PubMed: 31244959]

[145]. Mohammadi M, Dehghani P, Mohseninia A, Roozbehani M, Hemphill A, Hesamizadeh $\mathrm{K}$, Incorporation of the Tat cell-penetrating peptide into nanofibers improves the respective antitumor immune response, J. Cell. Physiol. 236 (2021) 1401-1417. [PubMed: 32686113]

[146]. Lim Y, Lee E, Lee M, Cell-penetrating-peptide-coated nanoribbons for intracellular nanocarriers, Angew. Chemie. 119 (2007) 3545-3548.

[147]. Tandon A, Pathak M, Harioudh MK, Ahmad S, Sayeed M, Afshan T, Siddiqi MI, Mitra K, Bhattacharya SM, Ghosh JK, A TLR4-derived non-cytotoxic, self-assembling peptide functions as a vaccine adjuvant in mice, J. Biol. Chem. 293 (2018) 19874-19885. [PubMed: 30385503]

[148]. Rudra JS, Tian YF, Jung JP, Collier JH, A self-assembling peptide acting as an immune adjuvant, Proc. Natl. Acad. Sci. U.S.A. 107 (2010) 622-627. [PubMed: 20080728]

[149]. Missirlis D, Khant H, Tirrell M, Mechanisms of peptide amphiphile internalization by SJSA-1 cells in vitro, Biochemistry 48 (2009) 3304-3314. [PubMed: 19245247]

[150]. Mukherjee S, Soe TT, Maxfield FR, Endocytic sorting of lipid analogues differing solely in the chemistry of their hydrophobic tails, J. Cell Biol. 144 (1999) 1271-1284. [PubMed: 10087269]

[151]. Tsunoda I, Sette A, Fujinami RS, Oseroff C, Ruppert J, Dahlberg C, Southwood S, Arrhenius T, Kuang LQ, Kubo RT, Chesnut RW, Ishioka GY, Lipopeptide particles as the immunologically active component of CTL inducing vaccines, Vaccine 17 (1999) 675-685. [PubMed: 10067673]

[152]. Black M, Trent A, Kostenko Y, Lee JS, Olive C, Tirrell M, Self-assembled peptide amphiphile micelles containing a cytotoxic T-cell epitope promote a protective immune response in vivo, Adv. Mater. 24 (2012) 3845-3849. [PubMed: 22550019]

[153]. Manolova V, Flace A, Bauer M, Schwarz K, Saudan P, Bachmann MF, Nanoparticles target distinct dendritic cell populations according to their size, Eur. J. Immunol. 38 (2008) 1404-1413. [PubMed: 18389478]

[154]. García-Piñeres AJ, Hildesheim A, Trivett M, Williams M, Wu L, KewalRamani VN, Pinto LA, Role of DC-SIGN in the activation of dendritic cells by HPV-16 L1 virus-like particle vaccine, Eur. J. Immunol. 36 (2006) 437-445. [PubMed: 16385626] 
[155]. Bandyopadhyay A, Fine RL, Demento S, Bockenstedt LK, Fahmy TM, The impact of nanoparticle ligand density on dendritic-cell targeted vaccines, Biomaterials 32 (2011) 3094 3105. [PubMed: 21262534]

[156]. Al-Barwani F, Young SL, Baird MA, Larsen DS, Ward VK, Mannosylation of virus-like particles enhances internalization by antigen presenting cells, PLoS ONE 9 (2014) e104523. [PubMed: 25122183]

[157]. Kawamura K, Kadowaki N, Suzuki R, Udagawa S, Kasaoka S, Utoguchi N, Kitawaki T, Sugimoto N, Okada N, Maruyama K, Uchiyama T, Dendritic cells that endocytosed antigencontaining IgG-liposomes elicit effective antitumor immunity, J. Immunother. 29 (2006) 165174. [PubMed: 16531817]

[158]. Hardy CL, LeMasurier JS, Mohamud R, Yao J, Xiang SD, Rolland JM, O'Hehir RE, Plebanski M, Differential uptake of nanoparticles and microparticles by pulmonary APC subsets induces discrete immunological imprints, J. Immunol. 191 (2013) 5278-5290. [PubMed: 24123688]

[159]. Fausch SC, Da Silva DM, Kast WM, Differential uptake and cross-presentation of human papillomavirus virus-like particles by dendritic cells and Langerhans cells, Cancer Res. 63 (2003) 3478-3482. [PubMed: 12839929]

[160]. Mohsen MO, Gomes AC, Vogel M, Bachmann MF, Interaction of viral capsid-derived virus-like particles (VLPs) with the innate immune system, Vaccines 6 (2018) 37.

[161]. Salick DA, Kretsinger JK, Pochan DJ, Schneider JP, Inherent antibacterial activity of a peptidebased $\beta$-hairpin hydrogel, J. Am. Chem. Soc. 129 (2007) 14793-14799. [PubMed: 17985907]

[162]. Chen W, Yang S, Li S, Lang JC, Mao C, Kroll P, Tang L, Dong H, Self-assembled peptide nanofibers display natural antimicrobial peptides to selectively kill bacteria without compromising cytocompatibility, ACS Appl. Mater. Interfaces. 11 (2019) 28681-28689. [PubMed: 31328913]

[163]. Mookherjee N, Anderson MA, Haagsman HP, Davidson DJ, Antimicrobial host defence peptides: functions and clinical potential, Nat. Rev. Drug Discov. 19 (2020) 311-332. [PubMed: 32107480]

[164]. Raheem N, Straus SK, Mechanisms of action for antimicrobial peptides with antibacterial and antibiofilm functions, Front. Microbiol. 10 (2019) 2866. [PubMed: 31921046]

[165]. Roggero E, Pérez AR, Bottasso OA, Besedovsky HO, Del Rey A, Neuroendocrine-immunology of experimental Chagas' disease, Ann. N. Y. Acad. Sci. 1153 (2009) 264-271. [PubMed: 19236349]

[166]. Mookherjee N, Brown KL, Bowdish DME, Doria S, Falsafi R, Hokamp K, Roche FM, Mu R, Doho GH, Pistolic J, Powers J-P, Bryan J, Brinkman FSL, Hancock REW, Modulation of the TLR-mediated inflammatory response by the endogenous human host defense peptide LL-3737, J. Immunol. 176 (2006) 2455-2464. [PubMed: 16456005]

[167]. Kindrachuk J, Jenssen H, Elliott M, Townsend R, Nijnik A, Lee SF, Gerdts V, Babiuk LA, Halperin SA, Hancock REW, A novel vaccine adjuvant comprised of a synthetic innate defence regulator peptide and $\mathrm{CpG}$ oligonucleotide links innate and adaptive immunity, Vaccine 27 (2009) 4662-4671. [PubMed: 19539585]

[168]. Jegerlehner A, Storni T, Lipowsky G, Schmid M, Pumpens P, Bachmann MF, Regulation of IgG antibody responses by epitope density and CD21-mediated costimulation, Eur. J. Immunol. 32 (2002) 3305-3314. [PubMed: 12555676]

[169]. Puffer EB, Pontrello JK, Hollenbeck JJ, Kink JA, Kiessling LL, Activating B cells signalling with defined multivalent ligands, ACS Chem. Biol. 2 (2007) 252-262. [PubMed: 17432821]

[170]. Wen Y, Collier JH, Supramolecular peptide vaccines: tuning adaptive immunity, Curr. Opin. Immunol 35 (2015) 73-79. [PubMed: 26163376]

[171]. Tostanoski LH, Jewell CM, Engineering self-assembled materials to study and direct immune function, Adv. Drug Deliv. Rev. 114 (2017) 60-78. [PubMed: 28392305]

[172]. Bennett NR, Zwick DB, Courtney AH, Kiessling LL, Multivalent antigens for promoting B and T cell activation, ACS Chem. Biol. 10 (2015) 1817-1824. [PubMed: 25970017]

[173]. Zepeda-Cervantes J, Ramírez-Jarquín JO, Vaca L, Interaction between virus-like particles (VLPs) and pattern recognition receptors (PRRs) from dendritic cells (DCs): toward better engineering of VLPs, Front. Immunol. 11 (2020) 1100. [PubMed: 32582186] 
[174]. Fries CN, Wu Y, Kelly SH, Wolf M, Votaw NL, Zauscher S, Collier JH, Controlled lengthwise assembly of helical peptide nanofibers to modulate CD8+ T-cell responses, Adv. Mater. 32 (2020) 2003310.

[175]. Miller KD, Roque R, Clegg CH, Novel anti-nicotine vaccine using a trimeric coiled-coil hapten carrier, PLoS ONE 9 (2014) 1-19.

[176]. Zeigler DF, Roque R, Clegg CH, Construction of an enantiopure bivalent nicotine vaccine using synthetic peptides, PLoS ONE 12 (2017) e0178835. [PubMed: 28570609]

[177]. Zeigler DF, Roque R, Clegg CH, Optimization of a multivalent peptide vaccine for nicotine addiction, Vaccine 37 (2019) 1584-1590. [PubMed: 30772068]

[178]. Bennett KM, Gorham RD, Gusti V, Trinh L, Morikis D, Lo DD, Hybrid flagellin as a T cell independent vaccine scaffold, BMC Biotechnol. 15 (2015) 71. [PubMed: 26265529]

[179]. Karch C, Paquin-Proulx D, Eller M, Matyas G, Burkhard P, Beck Z, Impact of the expression system on the immune responses to self-assembling protein nanoparticles (SAPNs) displaying HIV-1 V1V2 loop, Nanomedicine 29 (2020) 102255. [PubMed: 32615339]

[180]. El Bissati K, Zhou Y, Paulillo SM, Raman SK, Karch CP, Reed S, Estes A, Estes A, Lykins J, Burkhard $\mathrm{P}$, Engineering and characterization of a novel self assembling protein for Toxoplasma peptide vaccine in HLA-A* 11:01, HLA-A* 02:01 and HLA-B* 07:02 transgenic mice, Sci. Rep. 10 (2020) 1-13. [PubMed: 31913322]

[181]. Li J, Helal Z, Ladman B, Karch C, Gelb J, Burkhard P, Khan M, Nanoparticle vaccine for avian influenza virus: a challenge study against highly pathogenic H5N2 subtype, J. Virol. Antivir. Res. 7 (2018) 2.

[182]. Li J, Helal Z, Karch C, Mishra N, Girshick T, Garmendia A, Burkhard P, Khan M, A selfadjuvanted nanoparticle based vaccine against infectious bronchitis virus, PLoS ONE 13 (2018) e0203771. [PubMed: 30216376]

[183]. Pimentel TAPF, Yan Z, Jeffers SA, Holmes KV, Hodges RS, Burkhard P, Peptide nanoparticles as novel immunogens: design and analysis of a prototypic severe acute respiratory syndrome vaccine, Chem. Biol. Drug Des. 73 (2009) 53-61. [PubMed: 19152635]

[184]. Zeigler DF, Gage E, Roque R, Clegg CH, Epitope targeting with self-assembled peptide vaccines, NPJ Vaccines 4 (2019) 1-8. [PubMed: 30622742]

[185]. Rudra JS, Mishra S, Chong AS, Mitchell RA, Nardin EH, Nussenzweig V, Collier JH, Selfassembled peptide nanofibers raising durable antibody responses against a malaria epitope, Biomaterials 33 (2012) 6476-6484. [PubMed: 22695068]

[186]. Rudra JS, Sun T, Bird KC, Daniels MD, Gasiorowski JZ, Chong AS, Collier JH, Modulating adaptive immune responses to peptide self-assemblies, ACS Nano 6 (2012) 1557-1564. [PubMed: 22273009]

[187]. Carpenter SM, Nunes-Alves C, Booty MG, Way SS, Behar SM, A higher activation threshold of memory CD8+ T cells has a fitness cost that is modified by TCR affinity during tuberculosis, PLoS Pathog. 12 (2016) e1005380. [PubMed: 26745507]

[188]. Chesson CB, Huelsmann EJ, Lacek AT, Kohlhapp FJ, Webb MF, Nabatiyan A, Zloza A, Rudra JS, Antigenic peptide nanofibers elicit adjuvant-free CD8+ T cell responses, Vaccine 32 (2014) 1174-1180. [PubMed: 24308959]

[189]. Si Y, Wen Y, Kelly SH, Chong AS, Collier JH, Intranasal delivery of adjuvant-free peptide nanofibers elicits resident CD8+ T cell responses, J. Control. Release. 282 (2018) 120-130. [PubMed: 29673645]

[190]. Si Y, Tian Q, Zhao F, Kelly SH, Shores LS, Camacho DF, Sperling AI, Andrade MS, Collier $\mathrm{JH}$, Chong AS, Adjuvant-free nanofiber vaccine induces in situ lung dendritic cell activation and TH17 responses, Sci. Adv. 6 (2020) 995-1002.

[191]. Alexander J, Sidney J, Southwood S, Ruppert J, Oseroff C, Maewal A, Snoke K, Serra HM, Kubo RT, Sette A, Grey HM, Development of high potency universal DR-restricted helper epitopes by modification of high affinity DR-blocking peptides, Immunity 1 (1994) 751-761. [PubMed: 7895164]

[192]. Shores LS, Kelly SH, Hainline KM, Suwanpradid J, MacLeod AS, Collier JH, Multifactorial design of a supramolecular peptide anti-IL-17 vaccine toward the treatment of psoriasis, Front. Immunol. 11 (2020) 1855. [PubMed: 32973764] 
[193]. Mora-Solano C, Wen Y, Han H, Chen J, Chong AS, Miller ML, Pompano RR, Collier JH, Active immunotherapy for TNF-mediated inflammation using self-assembled peptide nanofibers, Biomaterials 149 (2017) 1-11. [PubMed: 28982051]

[194]. Hudalla GA, Modica JA, Tian YF, Rudra JS, Chong AS, Sun T, Mrksich M, Collier JH, A self-adjuvanting supramolecular vaccine carrying a folded protein antigen, Adv. Healthc. Mater. 2 (2013) 1114-1119. [PubMed: 23436779]

[195]. Hudalla GA, Sun T, Gasiorowski JZ, Han H, Tian YF, Chong AS, Collier JH, Gradated assembly of multiple proteins into supramolecular nanomaterials, Nat. Mater. 13 (2014) 829 836. [PubMed: 24930032]

[196]. Zhang H, Park J, Jiang Y, Woodrow KA, Rational design of charged peptides that self-assemble into robust nanofibers as immune-functional scaffolds, Acta Biomater 55 (2017) 183-193. [PubMed: 28365480]

[197]. Rudra JS, Ding Y, Neelakantan H, Ding C, Appavu R, Stutz S, Snook JD, Chen H, Cunningham KA, Zhou J, Suppression of cocaine-evoked hyperactivity by self-adjuvanting and multivalent peptide nanofiber vaccines, ACS Chem. Neurosci. 7 (2016) 546-552. [PubMed: 26926328]

[198]. Ding Y, Liu J, Lu S, Igweze J, Xu W, Kuang D, Zealey C, Liu D, Gregor A, Bozorgzad A, Zhang L, Yue E, Mujib S, Ostrowski M, Chen P, Self-assembling peptide for co-delivery of HIV-1 CD8+ T cells epitope and Toll-like receptor 7/8 agonists R848 to induce maturation of monocyte derived dendritic cell and augment polyfunctional cytotoxic T lymphocyte (CTL) response, J. Control. Release. 236 (2016) 22-30. [PubMed: 27297778]

[199]. Yang P, Song H, Qin Y, Huang P, Zhang C, Kong D, Wang W, Engineering dendritic-cell-based vaccines and PD-1 blockade in self-assembled peptide nanofibrous hydrogel to amplify antitumor T-cell immunity, Nano Lett. 18 (2018) 4377-4385. [PubMed: 29932335]

[200]. Grenfell RFQ, Shollenberger LM, Samli EF, Harn DA, Vaccine self-assembling immune matrix is a new delivery platform that enhances immune responses to recombinant HBsAg in mice, Clin. Vaccine Immunol. 22 (2015) 336-343. [PubMed: 25609075]

[201]. Yang C, Shi F, Li C, Wang Y, Wang L, Yang Z, Single dose of protein vaccine with peptide nanofibers as adjuvants elicits long-lasting antibody titer, ACS Biomater. Sci. Eng. 4 (2018) 2000-2006. [PubMed: 33445270]

[202]. Wang Y, Li X, Zhang Y, Wang L, Yang Z, A supramolecular hydrogel to boost the production of antibodies for phosphorylated proteins, Chem. Commun. 55 (2019) 12388-12391.

[203]. Friedrich BM, Beasley DWC, Rudra JS, Supramolecular peptide hydrogel adjuvanted subunit vaccine elicits protective antibody responses against West Nile virus, Vaccine 34 (2016) 54795482. [PubMed: 27670075]

[204]. Babych M, Bertheau-Mailhot G, Zottig X, Dion J, Gauthier L, Archambault D, Bourgault S, Engineering and evaluation of amyloid assemblies as a nanovaccine against the Chikungunya virus, Nanoscale 10 (2018) 19547-19556. [PubMed: 30324958]

[205]. Al-Halifa S, Zottig X, Babych M, Côté-Cyr M, Bourgault S, Archambault D, Harnessing the activation of Toll-like receptor $2 / 6$ by self-assembled cross- $\beta$ fibrils to design adjuvanted nanovaccines, Nanomaterials 10 (2020) 1981.

[206]. Huber VC, McKeon RM, Brackin MN, Miller LA, Keating R, Brown SA, Makarova N, Perez DR, MacDonald GH, McCullers JA, Distinct contributions of vaccine-induced immunoglobulin G1 (IgG1) and IgG2a antibodies to protective immunity against influenza, Clin. Vaccine Immunol. 13 (2006) 981-990. [PubMed: 16960108]

[207]. Li S, Zhu W, Ye C, Sun W, Xie H, Yang X, Zhang Q, Ma Y, Local mucosal immunization of self-assembled nanofibers elicits robust antitumor effects in an orthotopic model of mouse genital tumors, Nanoscale 12 (2020) 3076-3089. [PubMed: 31965136]

[208]. Huang Z-H, Shi L, Ma J-W, Sun Z-Y, Cai H, Chen Y-X, Zhao Y-F, Li Y-M, A totally synthetic, self-assembling, adjuvant-free MUC1 glycopeptide vaccine for cancer therapy, J. Am. Chem. Soc. 134 (2012) 8730-8733. [PubMed: 22587010]

[209]. Luo Z, Wu Q, Yang C, Wang H, He T, Wang Y, Wang Z, Chen H, Li X, Gong C, Yang Z, A powerful CD8+ T-cell stimulating d-tetra-peptide hydrogel as a very promising vaccine adjuvant, Adv. Mater. 29 (2017) 1601776. 
[210]. Wang Z, Liang C, Shi F, He T, Gong C, Wang L, Yang Z, Cancer vaccines using supramolecular hydrogels of NSAID-modified peptides as adjuvants abolish tumorigenesis, Nanoscale 9 (2017) 14058-14064. [PubMed: 28895610]

[211]. Wang Z, Shang Y, Tan Z, Li X, Li G, Ren C, Wang F, Yang Z, Liu J, A supramolecular protein chaperone for vaccine delivery, Theranostics 10 (2020) 657-670. [PubMed: 31903143]

[212]. Luo Z, Zhao X, Zhang S, Structural dynamic of a self-assembling peptide d-EAK16 made of only d-amino acids, PLoS ONE 3 (2008) e2364. [PubMed: 18509542]

[213]. Appavu R, Chesson CB, Koyfman AY, Snook JD, Kohlhapp FJ, Zloza A, Rudra JS, Enhancing the magnitude of antibody responses through biomaterial stereochemistry, ACS Biomater. Sci. Eng. 1 (2015) 601-609. [PubMed: 33434976]

[214]. Nagy KJ, Giano MC, Jin A, Pochan DJ, Schneider JP, Enhanced mechanical rigidity of hydrogels formed from enantiomeric peptide assemblies, J. Am. Chem. Soc. 133 (2011) 1497514977. [PubMed: 21863803]

[215]. Swanekamp RJ, DiMaio JTM, Bowerman CJ, Nilsson BL, Coassembly of enantiomeric amphipathic peptides into amyloid-inspired rippled $\beta$-sheet fibrils, J. Am. Chem. Soc. 134 (2012) 5556-5559. [PubMed: 22420540]

[216]. Melchionna M, Styan KE, Marchesan S, The unexpected advantages of using D-amino acids for peptide self-assembly into nanostructured hydrogels for medicine, Curr. Top. Med. Chem. 16 (2016) 2009-2018. [PubMed: 26876522]

[217]. Clover TM, O’Neill CL, Appavu R, Lokhande G, Gaharwar AK, Posey AE, White MA, Rudra JS, Self-assembly of block heterochiral peptides into helical tapes, J. Am. Chem. Soc. 142 (2020) 19809-19813. [PubMed: 32338879]

[218]. Swanekamp RJ, Welch JJ, Nilsson BL, Proteolytic stability of amphipathic peptide hydrogels composed of self-assembled pleated $\beta$-sheet or coassembled rippled $\beta$-sheet fibrils, Chem. Commun. 50 (2014) 10133-10136.

[219]. Yang C, Chu L, Zhang Y, Shi Y, Liu J, Liu Q, Fan S, Yang Z, Ding D, Kong D, Liu J, Dynamic biostability, biodistribution, and toxicity of L/D-peptide-based supramolecular nanofibers, ACS Appl. Mater. Interfaces. 7 (2015) 2735-2744. [PubMed: 25555064]

[220]. Tian Y, Wang H, Liu Y, Mao L, Chen W, Zhu Z, Liu W, Zheng W, Zhao Y, Kong D, Yang Z, Zhang W, Shao Y, Jiang X, A peptide-based nanofibrous hydrogel as a promising DNA nanovector for optimizing the efficacy of HIV vaccine, Nano Lett 14 (2014) 1439-1445. [PubMed: 24564254]

[221]. Wang H, Luo Z, Wang Y, He T, Yang C, Ren C, Ma L, Gong C, Li X, Yang Z, Enzymecatalyzed formation of supramolecular hydrogels as promising vaccine adjuvants, Adv. Funct. Mater. 26 (2016) 1822-1829.

[222]. Yoon YM, Lewis JS, Carstens MR, Campbell-Thompson M, Wasserfall CH, Atkinson MA, Keselowsky BG, A combination hydrogel microparticle-based vaccine prevents type 1 diabetes in non-obese diabetic mice, Sci. Rep. 5 (2015) 1-13.

[223]. Rudra JS, Banasik BN, Milligan GN, A combined carrier-adjuvant system of peptide nanofibers and toll-like receptor agonists potentiates robust CD8+ T cell responses, Vaccine 36 (2018) 438441. [PubMed: 29248267]

[224]. Barrett JC, Ulery BD, Trent A, Liang S, David NA, Tirrell MV, Modular peptide amphiphile micelles improving an antibody-mediated immune response to group A Streptococcus, ACS Biomater. Sci. Eng. 3 (2017) 144-152. [PubMed: 29242824]

[225]. Trent A, Ulery BD, Black MJ, Barrett JC, Liang S, Kostenko Y, David NA, Tirrell MV, Peptide amphiphile micelles self-adjuvant group A Streptococcal vaccination, AAPS J. 17 (2015) 380388. [PubMed: 25527256]

[226]. Zope H, Quer CB, Bomans PHH, Sommerdijk NAJM, Kros A, Jiskoot W, Peptide amphiphile nanoparticles enhance the immune response against a CpG-adjuvanted influenza antigen, Adv. Healthc. Mater. 3 (2014) 343-348. [PubMed: 23983195]

[227]. Poon C, Chowdhuri S, Kuo CH, Fang Y, Alenghat FJ, Hyatt D, Kani K, Gross ME, Chung EJ, Protein mimetic and anticancer properties of monocyte-targeting peptide amphiphile micelles, ACS Biomater. Sci. Eng. 3 (2017) 3273-3282. [PubMed: 29302619] 
[228]. Windberg J, Zhang R, MAGE-3 peptide amphiphile micelle vaccine promote anti-tumor immunity in mice with stomach cancer, BioRxiv (2019) 609214.

[229]. Abdel-Aal ABM, Batzloff MR, Fujita Y, Barozzi N, Faria A, Simerska P, Moyle PM, Good MF, Toth I, Structure-activity relationship of a series of synthetic lipopeptide self-adjuvanting group A Streptococcal vaccine candidates, J. Med. Chem. 51 (2008) 167-172. [PubMed: 18072728]

[230]. Zaman M, Abdel-Aal ABM, Fujita Y, Ziora ZM, Batzloff MR, Good MF, Toth I, Structureactivity relationship for the development of a self-adjuvanting mucosally active lipopeptide vaccine against Streptococcus pyogenes, J. Med. Chem. 55 (2012) 8515-8523. [PubMed: 22974133]

[231]. Zaman M, Chandrudu S, Giddam AK, Reiman J, Skwarczynski M, Mc-Phun V, Moyle PM, Batzloff MR, Good MF, Toth I, Group A Streptococcal vaccine candidate: contribution of epitope to size, antigen presenting cell interaction and immunogenicity, Nanomedicine 9 (2014) 26132624. [PubMed: 25529566]

[232]. Azmi F, Fuaad AAHA, Giddam AK, Batzloff MR, Good MF, Skwarczynski M, Toth I, Self-adjuvanting vaccine against group A Streptococcus: application of fibrillized peptide and immunostimulatory lipid as adjuvant, Bioorg. Med. Chem. 22 (2014) 6401-6408. [PubMed: 25438764]

[233]. Zhang R, Kramer JS, Smith JD, Allen BN, Leeper CN, Li X, Morton LD, Gallazzi F, Ulery BD, Vaccine adjuvant incorporation strategy dictates peptide amphiphile micelle immunostimulatory capacity, AAPS J. 20 (2018) 1-10.

[234]. Zhang R, Smith JD, Allen BN, Kramer JS, Schauflinger M, Ulery BD, Peptide amphiphile micelle vaccine size and charge influence the host antibody response, ACS Biomater. Sci. Eng. 4 (2018) 2463-2472. [PubMed: 33435110]

[235]. Demircan MB, Tohumeken S, Gunduz N, Khalily MA, Tekinay T, Guler MO, Tekinay AB, Biotin functionalized self-assembled peptide nanofiber as an adjuvant for immunomodulatory response, Biotechnol. J. 15 (2020) 2000100.

[236]. Cheng K, Ding Y, Zhao Y, Ye S, Zhao X, Zhang Y, Ji T, Wu H, Wang B, Anderson GJ, Ren L, Nie G, Sequentially responsive therapeutic peptide assembling nanoparticles for dual-targeted cancer immunotherapy, Nano Lett. 18 (2018) 3250-3258. [PubMed: 29683683]

[237]. Chung EJ, Mlinar LB, Sugimoto MJ, Nord K, Roman BB, Tirrell M, In vivo biodistribution and clearance of peptide amphiphile micelles, Nanomedicine 11 (2015) 479-487. [PubMed: 25194999]

[238]. Kassam HA, Bahnson EM, Cartaya A, Jiang W, Avram MJ, Tsihlis ND, Stupp SI, Kibbe MR, Pharmacokinetics and biodistribution of a collagen-targeted peptide amphiphile for cardiovascular applications, Pharmacol. Res. Perspect. 8 (2020) e00672. [PubMed: 33090704]

[239]. Skwarczynski M, Zhao G, Boer JC, Ozberk V, Azuar A, Cruz JG, Giddam AK, Khalil ZG, Pandey M, Shibu MA, Hussein WM, Nevagi RJ, Batzloff MR, Wells JW, Capon RJ, Plebanski M, Good MF, Toth I, Poly(amino acids) as a potent self-adjuvanting delivery system for peptidebased nanovaccines, Sci. Adv. 6 (2020) eaax2285.

[240]. Azuar A, Li Z, Shibu MA, Zhao L, Luo Y, Shalash AO, Khalil ZG, Capon RJ, Hussein WM, Toth I, Skwarczynski M, Poly(hydrophobic amino acid)-based self-adjuvanting nanoparticles for group A Streptococcus vaccine delivery, J. Med. Chem. 64 (2021) 2648-2658. [PubMed: 33529034]

[241]. Bartlett S, Eichenberger RM, Nevagi RJ, Ghaffar KA, Marasini N, Dai Y, Loukas A, Toth I, Skwarczynski M, Lipopeptide-based oral vaccine against hookworm infection, J. Infect. Dis. 221 (2020) 934-942. [PubMed: 31621864]

[242]. Bartlett S, Skwarczynski M, Xie X, Toth I, Loukas A, Eichenberger RM, Development of natural and unnatural amino acid delivery systems against hookworm infection, Precision Nanomed. 3 (2020) 471-482.

[243]. Rynda-Apple A, Patterson DP, Douglas T, Virus-like particles as antigenic nanomaterials for inducing protective immune responses in the lung, Nanomedicine (Lond.) 9 (2014) 1857-1868. [PubMed: 25325241] 
[244]. Negahdaripour M, Golkar N, Hajighahramani N, Kianpour S, Nezafat N, Ghasemi Y, Harnessing self-assembled peptide nanoparticles in epitope vaccine design, Biotechnol. Adv. 35 (2017) 575-596. [PubMed: 28522213]

[245]. Grgacic EVL, Anderson DA, Virus-like particles: passport to immune recognition, Methods 40 (2006) 60-65. [PubMed: 16997714]

[246]. Cohen BJ, Richmond JE, Electron microscopy of hepatitis B core antigen synthesized in E. coli, Nature 296 (1982) 677-678. [PubMed: 7040981]

[247]. Garland SM, Hernandez-Avila M, Wheeler CM, Perez G, Harper DM, Leodolter S, Tang GWK, Ferris DG, Steben M, Bryan J, Taddeo FJ, Railkar R, Esser MT, Sings HL, Nelson M, Boslego J, Sattler C, Barr E, Koutsky LA, Quadrivalent vaccine against human papillomavirus to prevent anogenital diseases, N. Engl. J. Med. 356 (2007) 1928-1943. [PubMed: 17494926]

[248]. Kirnbauer R, Booy F, Cheng N, Lowy DR, Schiller JT, Papillomavirus L1 major capsid protein self-assembles into virus-like particles that are highly immunogenic, Proc. Natl. Acad. Sci. U.S.A. 89 (1992) 12180-12184. [PubMed: 1334560]

[249]. Francis MJ, Hastings GZ, Brown AL, Grace KG, Rowlands DJ, Brown F, Clarke BE, Immunological properties of hepatitis B core antigen fusion proteins, Proc. Natl. Acad. Sci. U.S.A. 87 (1990) 2545-2549. [PubMed: 2320575]

[250]. Anderson R, Huang Y, Langley JM, Prospects for defined epitope vaccines for respiratory syncytial virus, Future Microbiol. 5 (2010) 585-602. [PubMed: 20353300]

[251]. Nardin EH, Oliveira GA, Calvo-Calle JM, Wetzel K, Maier C, Birkett AJ, Sarpotdar P, Corado ML, Thornton GB, Schmidt A, Phase I testing of a malaria vaccine composed of hepatitis B virus core particles expressing Plasmodium falciparum circumsporozoite epitopes, Infect. Immun. 72 (2004) 6519-6527. [PubMed: 15501783]

[252]. Schödel F, Peterson D, Hughes J, Wirtz R, Milich D, Hybrid hepatitis B virus core antigen as a vaccine carrier moiety: I. Presentation of foreign epitopes, J. Biotechnol. 44 (1996) 91-96. [PubMed: 8717391]

[253]. Molino NM, Anderson AKL, Nelson EL, Wang SW, Biomimetic protein nanoparticles facilitate enhanced dendritic cell activation and cross-presentation, ACS Nano 7 (2013) 9743-9752. [PubMed: 24090491]

[254]. Molino NM, Neek M, Tucker JA, Nelson EL, Wang SW, Viral-mimicking protein nanoparticle vaccine for eliciting anti-tumor responses, Biomaterials 86 (2016) 83-91. [PubMed: 26894870]

[255]. Caivano A, Doria-Rose NA, Buelow B, Sartorius R, Trovato M, D’ Apice L, Domingo GJ, Sutton WF, Haigwood NL, De Berardinis P, HIV-1 Gag p17 presented as virus-like particles on the E2 scaffold from Geobacillus stearothermophilus induces sustained humoral and cellular immune responses in the absence of IFN $\gamma$ production by CD4+ T cells, Virology 407 (2010) 296-305. [PubMed: 20850858]

[256]. Jaworski JP, Krebs SJ, Trovato M, Kovarik DN, Brower Z, Sutton WF, Waagmeester G, Sartorius R, D’Apice L, Caivano A, Doria-Rose NA, Malherbe D, Montefiori DC, Barnett S, De Berardinis P, Haigwood NL, Co-immunization with multimeric scaffolds and DNA rapidly induces potent autologous HIV-1 neutralizing antibodies and CD8+ T cells, PLoS ONE 7 (2012) 31464.

[257]. Krebs SJ, McBurney SP, Kovarik DN, Waddell CD, Jaworski JP, Sutton WF, Gomes MM, Trovato M, Waagmeester G, Barnett SJ, De Berardinis P, Haigwood NL, Multimeric scaffolds displaying the HIV-1 envelope MPER induce MPER-specific antibodies and cross-neutralizing antibodies when co-immunized with gp160 DNA, PLoS ONE 9 (2014) e113463. [PubMed: 25514675]

[258]. Lee EB, Jeon HM, Kim CU, Park SM, Cho G, Kim HJ, Kim Y, Kim DJ, Kim YS, Lee H, Lee $\mathrm{JO}$, Attachment of flagellin enhances the immunostimulatory activity of a hemagglutinin-ferritin nano-cage, Nanomedicine 17 (2019) 223-235. [PubMed: 30695729]

[259]. Maurer P, Bachmann M, Vaccination against nicotine: an emerging therapy for tobacco dependence, Expert Opin. Investig. Drugs. 16 (2007) 1775-1783.

[260]. Chackerian B, Virus-like particle based vaccines for Alzheimer disease, Hum. Vaccin. 6 (2010) 926-930. [PubMed: 20864801] 
[261]. Burton DR, Scaffolding to build a rational vaccine design strategy, Proc. Natl. Acad. Sci. U.S.A. 107 (2010) 17859-17860. [PubMed: 20937874]

[262]. Richardson C, Bargatze RF, Goodwin R, Mendelman PM, Norovirus virus-like particle vaccines for the prevention of acute gastroenteritis, Expert Rev. Vaccines. 12 (2013) 155-167. [PubMed: 23414407]

[263]. Voysey M, Clemens SAC, Madhi SA, Weckx LY, Folegatti PM, Aley PK, Angus B, Baillie VL, Barnabas SL, Bhorat QE, Bibi S, Briner C, Cicconi P, Collins AM, Colin-Jones R, Cutland CL, Darton TC, Dheda K, Duncan CJA, Emary KRW, Ewer KJ, Fairlie L, Faust SN, Feng S, Ferreira DM, Finn A, Goodman AL, Green CM, Green CA, Heath PT, Hill C, Hill H, Hirsch I, Hodgson SHC, Izu A, Jackson S, Jenkin D, Joe CCD, Kerridge S, Koen A, Kwatra G, Lazarus R, Lawrie AM, Lelliott A, Libri V, Lillie PJ, Mallory R, Mendes AVA, Milan EP, Minassian AM, McGregor A, Morrison H, Mujadidi YF, Nana A, O’Reilly PJ, Padayachee SD, Pittella A, Plested E, Pollock KM, Ramasamy MN, Rhead S, Schwarzbold AV, Singh N, Smith A, Song R, Snape MD, Sprinz E, Sutherland RK, Tarrant R, Thomson EC, Török ME, Toshner M, Turner DPJ, Vekemans J, Villafana TL, Watson MEE, Williams CJ, Douglas AD, Hill AVS, Lambe T, Gilbert SC, Pollard AJ, Aban M, Abayomi F, Abeyskera K, Aboagye J, Adam M, Adams K, Adamson J, Adelaja YA, Adlou S, Ahmed K, Akhalwaya Y, Akhalwaya S, Alcock A, Ali A, Allen ER, Allen L, Almeida TCDSC, Alves MPS, Amorim F, Andritsou F, Anslow R, Appleby M, Arbe-Barnes EH, Ariaans MP, Arns B, Arruda L, Awedetan G, Azi P, Azi L, Babbage G, Bailey C, Baker KF, Baker M, Baker N, Baker P, Baldwin L, Baleanu I, Bandeira D, Bara A, Barbosa MAS, Barker D, Barlow GD, Barnes E, Barr AS, Barrett JR, Barrett J, Bates L, Batten A, Beadon K, Beales E, Beckley R, Belij-Rammerstorfer S, Bell J, Bellamy D, Bellei N, Belton S, Berg A, Bermejo L, Berrie E, Berry L, Berzenyi D, Beveridge A, Bewley KR, Bexhell H, Bhikha S, Bhorat AE, Bhorat ZE, Bijker E, Birch G, Birch S, Bird A, Bird O, Bisnauthsing K, Bittaye M, Blackstone K, Blackwell L, Bletchly H, Blundell CL, Blundell SR, Bodalia P, Boettger BC, Bolam E, Boland E, Bormans D, Borthwick N, Bowring F, Boyd A, Bradley P, Brenner T, Brown P, Brown C, Brown-O'Sullivan C, Bruce S, Brunt E, Buchan R, Budd W, Bulbulia YA, Bull M, Burbage J, Burhan H, Burn A, Buttigieg KR, Byard N, Cabera Puig I, Calderon G, Calvert A, Camara S, Cao M, Cappuccini F, Cardoso JR, Carr M, Carroll MW, Carson-Stevens A, de M. Carvalho Y, Carvalho JAM, Casey HR, Cashen P, Castro T, Castro LC, Cathie K, Cavey A, Cerbino-Neto J, Chadwick J, Chapman D, Charlton S, Chelysheva I, Chester O, Chita S, Cho JS, Cifuentes L, Clark E, Clark M, Clarke A, Clutterbuck EA, Collins SLK, Conlon CP, Connarty S, Coombes N, Cooper C, Cooper R, Cornelissen L, Corrah T, Cosgrove C, Cox T, Crocker WEM, Crosbie S, Cullen L, Cullen D, Cunha DRMF, Cunningham C, Cuthbertson FC, Da Guarda SNF, da Silva LP, Damratoski BE, Danos Z, Dantas MTDC, Darroch P, Datoo MS, Datta C, Davids M, Davies SL, Davies H, Davis E, Davis J, Davis J, De Nobrega MMD, De Oliveira Kalid LM, Dearlove D, Demissie T, Desai A, Di Marco S, Di Maso C, Dinelli MIS, Dinesh T, Docksey C, Dold C, Dong T, Donnellan FR, Dos Santos T, dos Santos TG, Dos Santos EP, Douglas N, Downing C, Drake J, Drake-Brockman R, Driver K, Drury R, Dunachie SJ, Durham BS, Dutra L, Easom NJW, van Eck S, Edwards M, Edwards NJ, El Muhanna OM, Elias SC, Elmore M, English M, Esmail A, Essack YM, Farmer E, Farooq M, Farrar M, Farrugia L, Faulkner B, Fedosyuk S, Felle S, Ferreira Da Silva C, Field S, Fisher R, Flaxman A, Fletcher J, Fofie H, Fok H, Ford KJ, Fowler J, Fraiman PHA, Francis E, Franco MM, Frater J, Freire MSM, Fry SH, Fudge S, Furze J, Fuskova M, Galian-Rubio P, Galiza E, Garlant H, Gavrila M, Geddes A, Gibbons KA, Gilbride C, Gill H, Glynn S, Godwin K, Gokani K, Goldoni UC, Goncalves M, Gonzalez IGS, Goodwin J, Goondiwala A, Gordon-Quayle K, Gorini G, Grab J, Gracie L, Greenland M, Greenwood N, Greffrath J, Groenewald MM, Grossi L, Gupta G, Hackett M, Hallis B, Hamaluba M, Hamilton E, Hammersley D, Hanrath AT, Hanumunthadu B, Harris SA, Harris C, Harris T, Harrison TD, Harrison D, Hart TC, Hartnell B, Hassan S, Haughney J, Hawkins S, Hay J, Head I, Henry J, Hermosin Herrera M, Hettle DB, Hill J, Hodges G, Horne E, Hou MM, Houlihan C, Howe E, Howell N, Humphreys J, Humphries HE, Hurley K, Huson C, Hyder-Wright A, Hyamns C, Ikram S, Ishwarbhai A, Ivan M, Iveson P, Iyer V, Jackson F, De Jager J, Jaumdally S, Jeffers H, Jesudason N, Jones B, Jones K, Jones E, Jones C, Jorge MR, Jose A, Joshi A, Júnior EAMS, Kadziola J, Kailath R, Kana F, Karampatsas K, Kasanyinga M, Keen J, Kelly EJ, Kelly DM, Kelly D, Kelly S, Kerr D, de Á. Kfouri R, Khan L, Khozoee B, Kidd S, Killen A,Kinch J, Kinch P, King LDW, King TB, Kingham L, Klenerman P, Knapper F, Knight JC, Knott D, Koleva S, Lang M, Lang G, Larkworthy CW, Larwood JPJ, Law R, Lazarus 
EM, Leach A, Lees EA, Lemm NM, Lessa A, Leung S, Li Y, Lias AM, Liatsikos K, Linder A, Lipworth S, Liu S, Liu X, Lloyd A, Lloyd S, Loew L, Lopez Ramon R, Lora L, Lowthorpe V, Luz K, MacDonald JC, MacGregor G, Madhavan M, Mainwaring DO, Makambwa E, Makinson R, Malahleha M, Malamatsho R, Mallett G, Mansatta K, Maoko T, Mapetla K, Marchevsky NG, Marinou S, Marlow E, Marques GN, Marriott P, Marshall RP, Marshall JL, Martins FJ, Masenya M, Masilela M, Masters SK, Mathew M, Matlebjane H, Matshidiso K, Mazur O, Mazzella A, McCaughan H, McEwan J, McGlashan J, McInroy L, McIntyre Z, McLenaghan D, McRobert N, McSwiggan S, Megson C, Mehdipour S, Meijs W, Mendonça RNÁ, Mentzer AJ, Mirtorabi N, Mitton C, Mnyakeni S, Moghaddas F, Molapo K, Moloi M, Moore M, Moraes-Pinto MI, Moran M, Morey E, Morgans R, Morris S, Morris S, Morris HC, Morselli F, Morshead G, Morter R, Mottal L, Moultrie A, Moya N, Mpelembue M, Msomi S, Mugodi Y, Mukhopadhyay E, Muller J, Munro A, Munro C, Murphy S, Mweu P, Myasaki CH, Naik G, Naker K, Nastouli E, Nazir A, Ndlovu B, Neffa F, Njenga C, Noal H, Noé A, Novaes G, Nugent FL, Nunes G, O’Brien K, O’Connor D, Odam M, Oelofse S, Oguti B, Olchawski V, Oldfield NJ, Oliveira MG, Oliveira C, Oosthuizen A, O'Reilly P, Osborne P, Owen DRJ, Owen L, Owens D, Owino N, Pacurar M, Paiva BVB, Palhares EMF, Palmer S, Parkinson S, Parracho HMRT, Parsons K, Patel D, Patel B, Patel F, Patel K, Patrick-Smith M, Payne RO, Peng Y, Penn EJ, Pennington A, Peralta Alvarez MP, Perring J, Perry N, Perumal R, Petkar S, Philip T, Phillips DJ, Phillips J, Phohu MK, Pickup L, Pieterse S, Piper J, Pipini D, Plank M, Du Plessis J, Pollard S, Pooley J, Pooran A, Poulton I, Powers C, Presa FB, Price DA, Price V, Primeira M, Proud PC, Provstgaard-Morys S, Pueschel S, Pulido D, Quaid S, Rabara R, Radford A, Radia K, Rajapaska D, Rajeswaran T, Ramos ASF, Ramos Lopez F, Rampling T, Rand J, Ratcliffe H, Rawlinson T, Rea D, Rees B, Reiné J, Resuello-Dauti M, Reyes Pabon E, Ribiero CM, Ricamara M, Richter A, Ritchie N, Ritchie AJ, Robbins AJ, Roberts H, Robinson RE, Robinson H, Rocchetti TT, Rocha BP, Roche S, Rollier C, Rose L, Ross Russell AL, Rossouw L, Royal S, Rudiansyah I, Ruiz S, Saich S, Sala C, Sale J, Salman AM, Salvador N, Salvador S, Sampaio M, Samson AD, Sanchez-Gonzalez A, Sanders H, Sanders K, Santos E, Santos Guerra MFS, Satti I, Saunders JE, Saunders C, Sayed A, Schimvan der Loeff I, Schmid AB, Schofield E, Screaton G, Seddiqi S, Segireddy RR, Senger, Serrasno S, Shah R, Shaik, Sharpe HE, Sharrocks, Shaw, Shea A, Shepherd A, Shepherd JG, Shiham F, Sidhom E, Silk SE, da Silva Moraes AC, Silva-Junior G, Silva-Reyes L, Silveira AD, Silveira MBV, Sinha J, Skelly DT, Smith DC, Smith N, Smith HE, Smith DJ, Smith CC, Soares A, Soares T, Solórzano C, Sorio GL, Sorley K, Sosa-Rodriguez T, Souza CMCDL, Souza BSDF, Souza AR, Spencer AJ, Spina F, Spoors L, Stafford L, Stamford I, Starinskij I, Stein R, Steven J, Stockdale L, Stockwell LV, Strickland LH, Stuart AC, Sturdy A, Sutton N, Szigeti A, Tahiri-Alaoui A, Tanner R, Taoushanis C, Tarr AW, Taylor K, Taylor U, Taylor IJ, Taylor J, te Water Naude R, Themistocleous Y, Themistocleous A, Thomas M, Thomas K, Thomas TM, Thom-brayil A, Thompson F, Thompson A, Thompson K, Thompson A, Thomson J, Thornton-Jones V, Tighe PJ, Tinoco LA, Tiongson G, Tladinyane B, Tomasicchio M, Tomic A, Tonks S, Tran N, Tree J, Trillana G, Trinham C, Trivett R, Truby A, Tsheko BL, Turabi A, Turner R, Turner C, Ulaszewska M, Underwood BR, Varughese R, Verbart D, Verheul M, Vichos I, Vieira T, Waddington CS, Walker L, Wallis E, Wand M, Warbick D, Wardell T, Warimwe G, Warren SC, Watkins B, Watson E, Webb S, Webb-Bridges A, Webster A, Welch J, Wells J, West A, White C, White R, Williams P, Williams RL, Winslow R, Woodyer M, Worth AT, Wright D, Wroblewska M, Yao A, Zimmer R, Zizi D, Zuidewind P, Safety and efficacy of the ChAdOx1 nCoV-19 vaccine (AZD1222) against SARS-CoV-2: an interim analysis of four randomised controlled trials in Brazil, South Africa, and the UK, Lancet 397 (2020) 99-111. [PubMed: 33306989]

[264]. Gelain F, Luo Z, Rioult M, Zhang S, Self-assembling peptide scaffolds in the clinic, Npj Regen. Med. 6 (2021) 9. [PubMed: 33597509] 


\section{Statement of significance}

Subunit vaccines have recently gained considerable attention due to their favorable safety profiles relative to traditional whole-cell vaccines; however, their reduced efficacy requires co-administration of reactogenic adjuvants to boost immune responses. This has led to collaborative efforts between engineers and immunologists to develop nanomaterial-based vaccination platforms that can elicit protection without deleterious side effects. Self-assembling peptidic biomaterials are a particularly attractive approach to this problem, as their structure and function can be controlled through primary sequence design and their capacity for multivalent presentation of antigens grants them intrinsic self-adjuvanticity. This review introduces the various architectures adopted by self-assembling peptides and discusses their application as modulators of innate and adaptive immunity. 
A

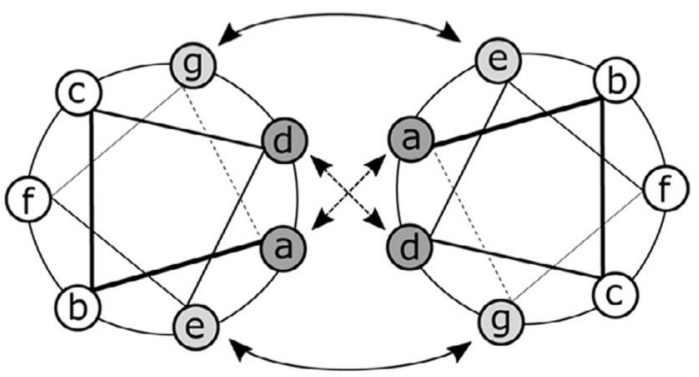

D

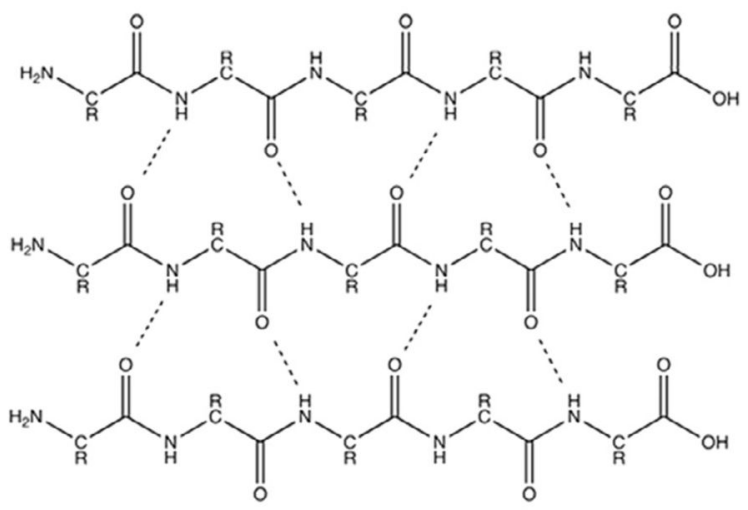

B

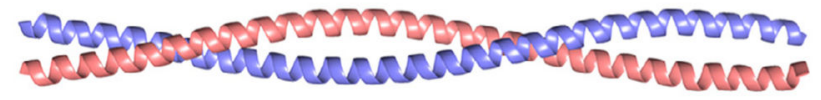

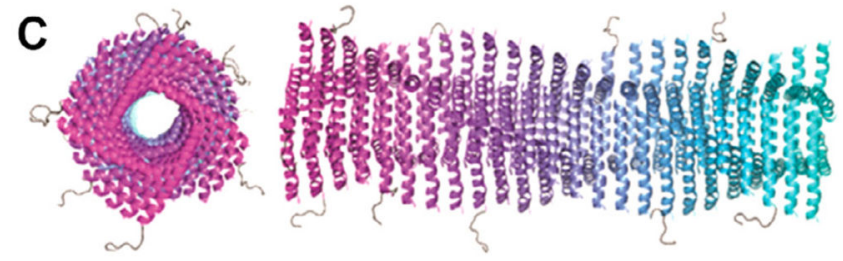

$E$

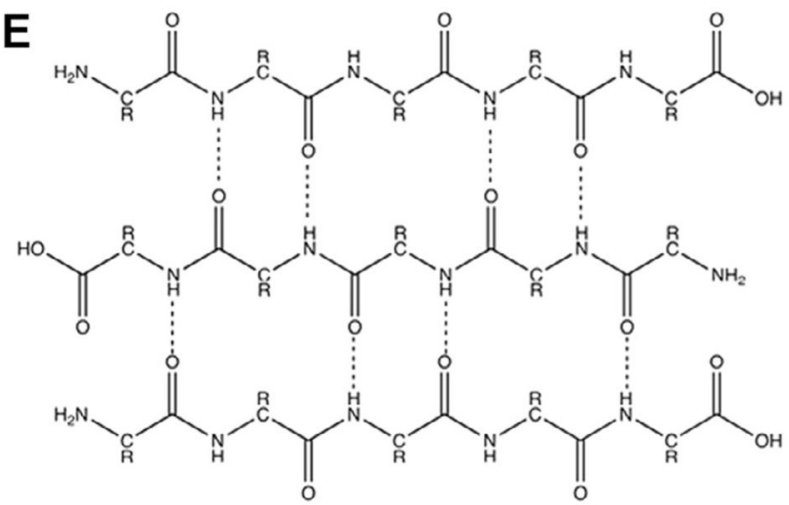
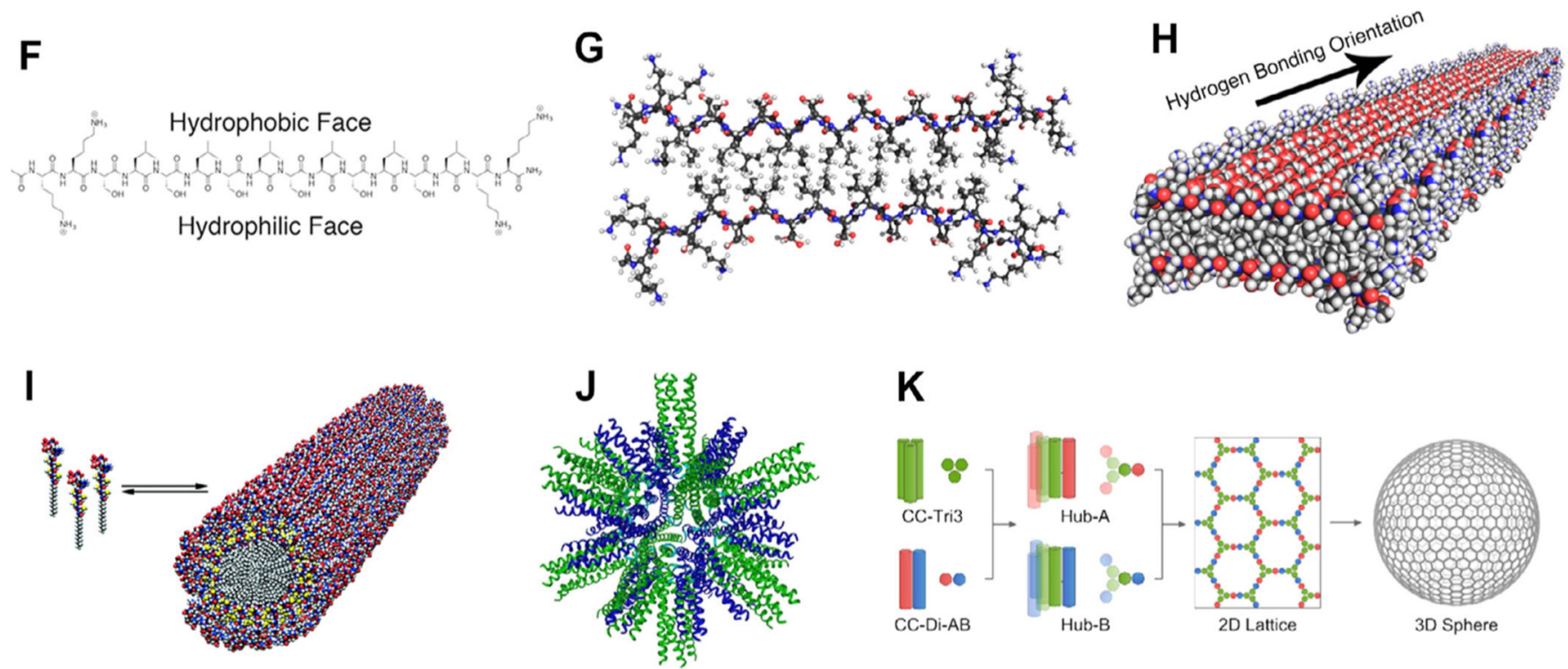

Fig. 1.

Supramolecular peptide, peptide amphiphile, and protein subunit nanoparticle structures. (A,B) Coiled coils are oligomers composed of two or more $a$-helices that typically display an abcdefg heptad repeat [33]. (C) Coil29 self-assembles into filamentous nanotubes in which individual coiled coil peptides associate with their $\mathrm{N}$-termini facing radially outward (adapted with permission from [34], copyright 2017 American Chemical Society). $\beta$-sheets adopt either (D) parallel or (E) antiparallel orientation, both of which are stabilized by extensive hydrogen bonding networks [35]. $\beta$-sheets with alternating hydrophilic and 
hydrophobic residues are $(\mathrm{F})$ facially amphipathic and $(\mathrm{G})$ laminate into bilayers that $(\mathrm{H})$ propagate along the hydrogen bonding axis (adapted with permission from [36], copyright 2017 American Chemical Society). (I) Peptide amphiphiles contain peptide head groups and lipid tails that assemble into cylindrical or spherical micelles (reprinted with permission from AAAS [37]). (J) Protein subunit nanoparticles incorporating trimeric and pentameric coiled coils assembly into polyhedral nanoparticles (adapted from [27], copyright 2006, with permission from Elsevier). (K) Coiled coil homotrimers covalently linked to the components of a heterodimeric coiled coil through disulfide bridges interact to form a hexagonal lattice that gives rise to closed nanocages (adapted with permission from [38], copyright 2018 American Chemical Society). 


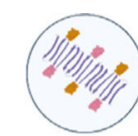

Nanofibers

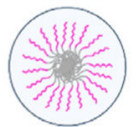

Nanoparticles

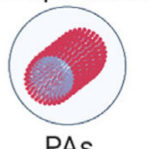

PAs

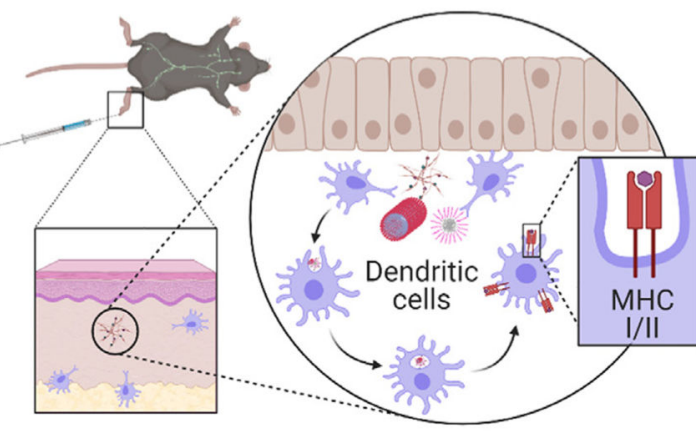

(1)

Injection of self-assembled peptide vaccines

\section{(2)}

Uptake by dendritic cells (DCs) and antigen presentation

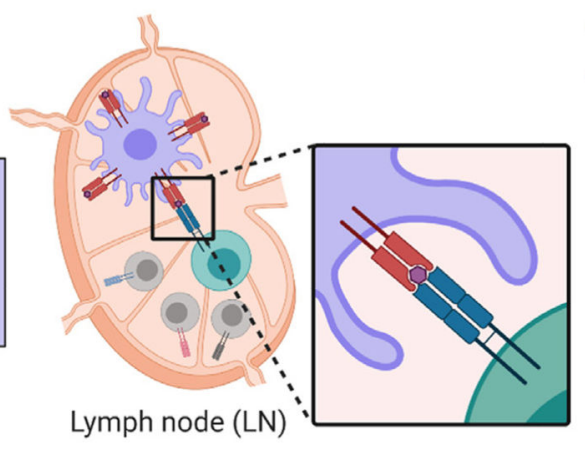

(3)

DC-mediated T cell activation in the LNs

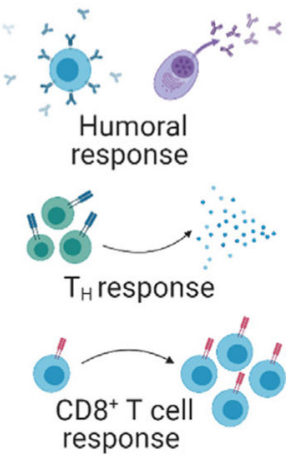

(4)

Immune response generated

Fig. 2.

Evolution of immune responses following supramolecular peptide-based vaccine delivery.

After vaccine administration (1), tissue resident APCs such as DCs and MФs internalize the constructs and process them through either the exogenous or endogenous pathway to present the antigenic epitopes on MHC II or MHC I molecules, respectively (2). The antigen-laden APCs then migrate to the dLNs for antigen presentation to $\mathrm{CD}^{+}{ }^{+}$or $\mathrm{CD}^{+}$ $\mathrm{T}$ cells. The interaction between MHC molecules and TCRs is supported by costimulatory signals, including ligand-receptor interactions and cytokine signaling, which enhance $\mathrm{T}$ cell responses and drive differentiation (3). $\mathrm{T}_{\mathrm{H}}$ cells then direct further immune activation through cytokine signaling and interaction with B cells and $\mathrm{CD} 8^{+} \mathrm{T}$ cells. Activated $\mathrm{B}$ cells interact with antigen-specific $\mathrm{T}$ cells and differentiate into plasma cells that produce long-lived antibody responses. Crosstalk between $\mathrm{CD}^{+}$and $\mathrm{CD}^{+} \mathrm{T}$ cells leads to the production of cytotoxic T lymphocytes that detect and eliminate infected cells (4). Created with https://www.BioRender.com. 